\title{
Vitamin D and cancer
}

\author{
Laura Vuolo $^{1}{ }^{*}$, Carolina Di Somma ${ }^{2}$, Antongiulio Faggiano ${ }^{1}$ and Annamaria Colao ${ }^{1}$ \\ Department of Molecular and Clinical Endocrinology and Oncology, "Federico II" University of Naples, Naples, Italy \\ ${ }^{2}$ Istituto di Ricovero e Cura a Carattere Scientifico SDN Foundation, Naples, Italy
}

\section{Edited by:}

Antonino Belfiore, University Magna

Graecia of Catanzaro, Italy

\section{Reviewed by:}

Antonino Belfiore, University Magna

Graecia of Catanzaro, Italy

Roberta Malaguarnera, University

Magna Graecia of Catanzaro, Italy

\section{*Correspondence:}

Laura Vuolo, Department of Molecular and Clinical Endocrinology and

Oncology, "Federico II" University of Naples, 80138 Naples, Italy.

e-mail: lauravuolo@tiscali.it
Vitamin D system is a complex pathway that includes precursors, active metabolites, enzymes, and receptors. This complex system actives several molecular pathways and mediates a multitude of functions. In addition to the classical role in calcium and bone homeostasis, vitamin D plays "non-calcemic" effects in host defense, inflammation, immunity, and cancer processes as recognized in vitro and in vivo studies. The aim of this review is to highlight the relationship between vitamin $D$ and cancer, summarizing several mechanisms proposed to explain the potential protective effect of vitamin $D$ against the development and progression of cancer. Vitamin D acts like a transcription factor that influences central mechanisms of tumorigenesis: growth, cell differentiation, and apoptosis. In addition to cellular and molecular studies, epidemiological surveys have shown that sunlight exposure and consequent increased circulating levels of vitamin D are associated with reduced reduced occurrence and a reduced mortality in different histological types of cancer. Another recent field of interest concerns polymorphisms of vitamin $D$ receptor (VDR); in this context, preliminary data suggest that VDR polymorphisms more frequently associated with tumorigenesis are Fok1, Bsm1, Taq1, Apa1, EcoRV, Cdx2; although further studies are needed to clarify their role in the cancer. In this review, the relationship between vitamin $\mathrm{D}$ and cancer is discussed.

Keywords: Vitamin D, 25-hydroxy-vitamin D, cancer, inflammation, immunity

\section{VITAMIN D PATHWAY VITAMIN D SYNTHESIS}

The vitamin $\mathrm{D}$ system includes a group of fat-soluble prohormones and their respective metabolites. There are two main forms of vitamin D in nature: vitamin D2 (ergocalciferol) photochemically synthesized in plants, and vitamin D3 (cholecalciferol) synthesized in the skin of animals and humans in response to sunlight too, in particular to ultraviolet B radiations of appropriate wavelength: $270-300 \mathrm{~nm}$. In most countries in Europe and in the US the requirement of vitamin D is given by $90 \%$ of the 7-dehydrocholesterol cholesterol synthesis in the skin from solar irradiation and only about $10 \%$ are taken up by the diet (Norman, 1998). The classical synthetic pathway involves 25 - and 1-alphahydroxylation of vitamin D2 and D3, in the liver and kidney, respectively. First hydroxylation occurs within the liver and lead to the formation of $25(\mathrm{OH}) \mathrm{D}$ or calcidiol; second hydroxylation occurs within the kidneys and constitutes the most biologically active hormonal form of vitamin D: $1,25(\mathrm{OH}) 2 \mathrm{D}$, or calcitriol (Figure 1). Vitamin D compounds are transported by a specific binding protein, vitamin D binding protein (DBP). Vitamin D activity is limited by catabolic processes, mediated primarily by a 24-hydroxylase (CYP24A1) which transforms the calcitriol in $1,24,25(\mathrm{OH}) 3 \mathrm{D}$, a compound with a substantially lower affinity for the vitamin D receptor (VDR); this catabolite is further metabolized to products which are then excreted such as calcitroic acid. Vitamin D metabolism is complex and tightly regulated. Rate limiting steps in the metabolism of vitamin D compounds are the activity of CYP2R1 which is induced by low $25(\mathrm{OH}) \mathrm{D}$ levels and the activity of CYP24A1 which is induced by $25(\mathrm{OH}) \mathrm{D}$ and 1,25(OH)2D (Tuohimaa, 2008). While vitamin D metabolizing enzymes are located primarily in liver (CYP2R1) and kidney (CYP27B1 and CYP24), catabolic enzymes are found in several tissues. It has been demonstrated that potential vitamin D target tissues (e.g., colon, prostate, breast, lung, pancreas) can synthesize and degrade calcitriol. Local production and degradation of calcitriol have been suggested to represent a key factors in several types of human cancer (Haussler et al., 1998; Schwartz et al., 2004; Cross, 2007).

\section{BIOLOGICAL ACTIVITY}

The traditionally recognized role of vitamin D consist in the regulation of bone metabolism and calcium-phosphorus homeostasis but recently a lot of in vitro and in vivo studies recognized several "non-calcemic" effects of vitamin D metabolites. Reduced levels of vitamin D are linked with the onset and progression of various diseases such as autoimmune diseases, respiratory infections, diabetes mellitus type 1 and type 2, hypertension and cardiovascular disease, neuromuscular disorders, and cancer (Holick and Chen, 2008). Higher vitamin D exposure is hypothesized to prevent several cancers, possibly through genomic effects modulated by the VDR, and non-genomic effects: autocrine/paracrine metabolism of the VDR's ligands. The $1,25(\mathrm{OH}) 2 \mathrm{D}$ is a well-known potent regulator of cell growth and differentiation, there is a recent evidence of an effect on cell death, tumor invasion, and angiogenesis, which makes it a candidate agent for cancer regulation. Calcitriol exerts significant antitumoral activity in vitro and in vivo in: murine squamous cell carcinoma (SCC), rat metastatic prostatic adenocarcinoma Dunning (MLL) model systems, human prostatic 


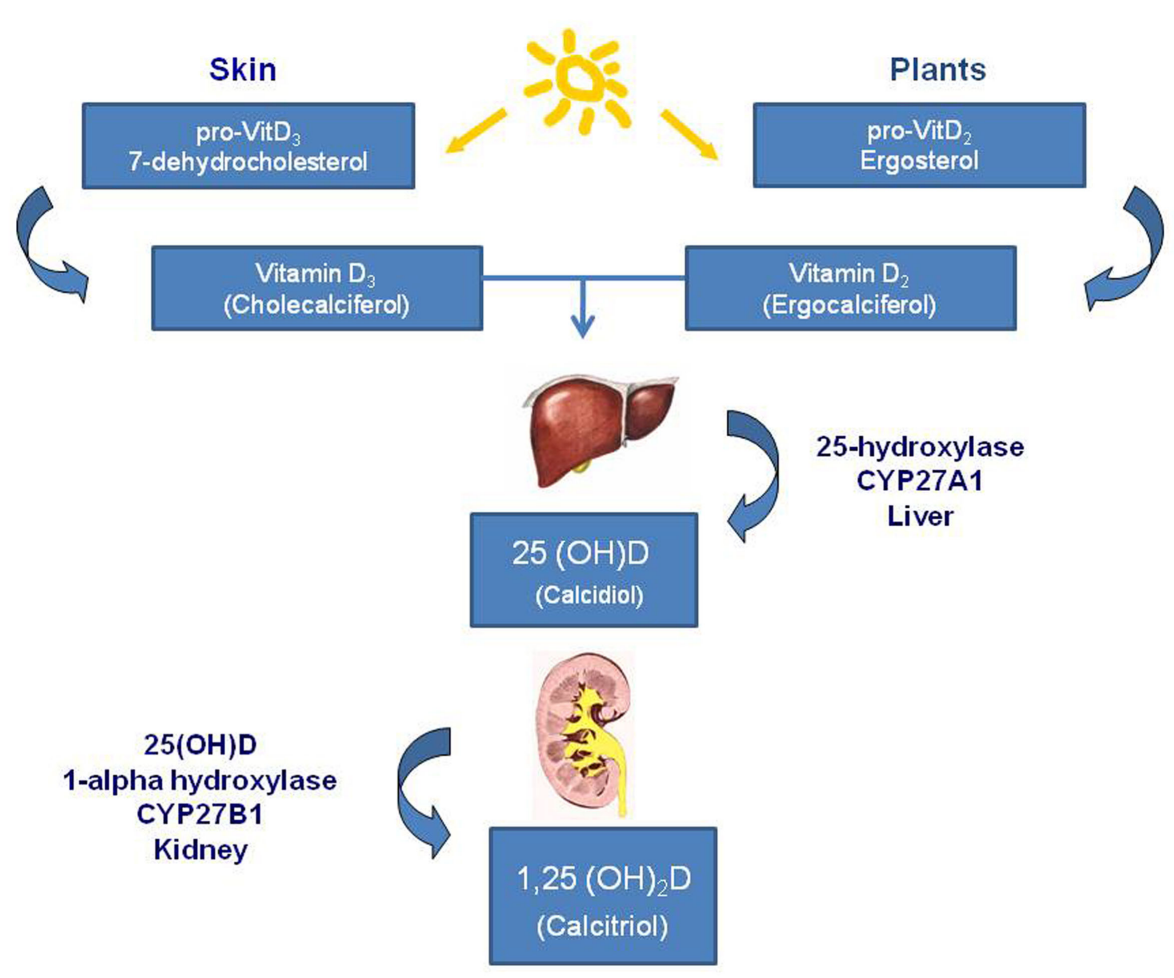

FIGURE 1 | Vitamin D synthesis. Main forms of vitamin D in nature are: vitamin D2 (ergocalciferol) that is photochemically synthesized in plants, and vitamin D3 (cholecalciferol) that is synthesized in the skin of animals and humans in response to sunlight. The synthetic pathway involves 25- and 1-alpha-hydroxylation of vitamin D2 and
D3, in the liver and kidney, respectively. First hydroxylation occurs within the liver and lead to the formation of 25(OH)D or calcidiol; second hydroxylation occurs within the kidneys and constitutes the most biologically active hormonal form of vitamin D: 1,25(OH)2D, or calcitriol. adenocarcinoma (PC-3 and LNCaP), human breast, colon, and pancreatic cancer, as well as in leukemia, myeloma, and lymphoma lines (Reichekl et al., 1989; Zhou et al., 1990; Uhmann et al., 2011).

\section{GENOMIC AND NON-GENOMIC ACTIONS}

Vitamin D and its analogous exert their effects through both genomic and non-genomic pathways. 1,25(OH)2D operates through pharmacologically distinct nuclear receptor-mediated and plasma membrane-initiated mechanisms. 1,25(OH)2D interacts with the VDR localized in the cell nucleus to generate genomic effects or in caveolae of the plasma membrane to generate nongenomic effects (rapid responses, RR). VDR is an intracellular nuclear receptor active in over 30 different human tissues, its activation involves over 60 genes in different cell lines. VDR are distributed in many organs and tissues as follows: Cardiovascular system: cardiomyocytes, smooth muscle cells; Endocrine system: thyroid C-cells, parathyroid glands, Langerhans islets; Epidermis: hair follicles, keratocytes; Gastrointestinal System: stomach, esophagus, intestine, liver; Immune System: thymus, T and B lymphocytes, bone marrow; Renal system: ascending portion of Henle loop, juxtaglomerular cells; Respiratory system: alveolar epithelium; Osteomuscular system: osteoblasts, chondrocytes, striated muscle; Reproductive system: testis, ovary, and uterus; Central nervous system: neurons.
In particular, both benign and malignant proliferative cells express the VDR. Calcitriol bound to VDR forms heterodimers with the retinoid $\mathrm{X}$ receptor (RXR) and its ligand (9 cis-retinoic acid) and these dimers occupy specific nucleotide sequences (vitamin D response elements or VDREs). In conjunction with several transcription factors, this complex lead to the transcription of vitamin D responsive genes (Figure 2). Among the numerous genes transcriptionally activated by calcitriol there are CYP24A1, BGLAP (osteocalcin), and CDKN1A (encoding p21Waf1/Cip1), the growth arrest and DNA-damage-inducible gene, GADD45 gene; while the parathyroid hormone (PTH) gene is repressed by calcitriol (Evans, 1988; Deeb et al., 2007).

Non-genomic pathways may cooperate with the classical genomic pathway (Figure 3). Non-genomic signaling is rapid, does not depend on transcription and may indirectly affect transcription via cross-talk with other signaling pathway. Some data suggest that non-genomic effects begin at the plasma membrane and involve a non-classical membrane receptor and a novel receptor for 1,25(OH)2D called 1,25D3-MARRS (membrane-associated, rapid response steroid-binding; Nemere et al., 2004; Norman, 2006). Non-genomic actions of calcitriol induce the rapid translocation of calcium across intestinal mucosal membranes. Binding of $1,25(\mathrm{OH}) 2 \mathrm{D}$ at plasma membrane may result in the activation of one or more second messenger systems, including phospholipase $\mathrm{C}(\mathrm{PKC})$, protein kinase $\mathrm{C}$, G protein-coupled receptors, 


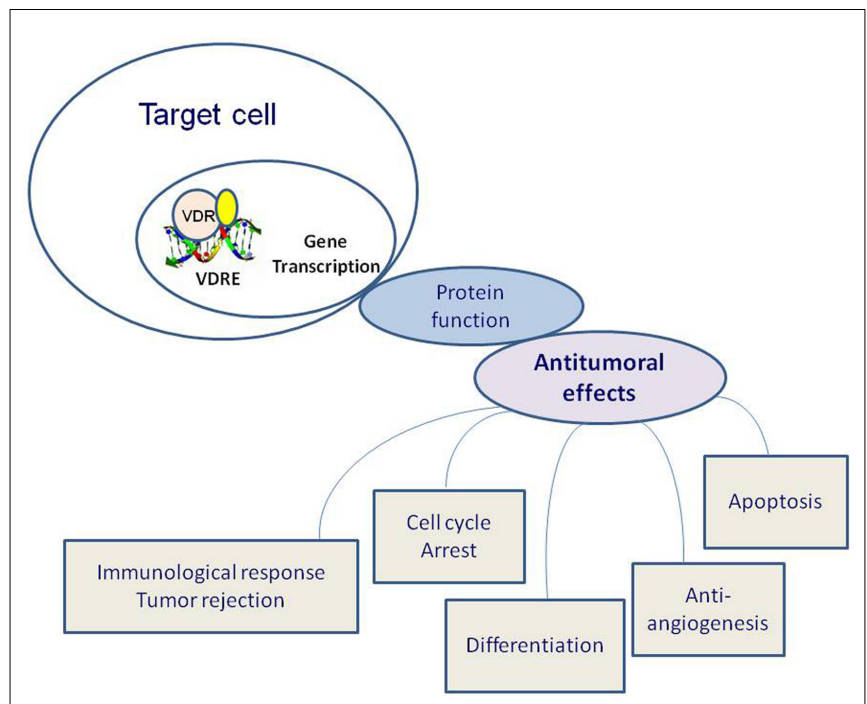

FIGURE 2 | Effects of vitamin D receptor (VDR) activation on tumorigenesis. Calcitriol bound to VDR forms heterodimers with the retinoid X receptor (RXR) and its ligand (9 cis-retinoic acid), these dimers occupy specific nucleotide sequences: vitamin $D$ response elements (VDREs). In conjunction with several transcription factors, this complex lead to the transcription of vitamin $D$ responsive genes.

or phosphatidylinositol-3-kinase (PI3K). There are a number of possible outcomes including opening of the voltage-gated calcium or chloride channels or generation of the second messengers. Some of these second messengers, particularly RAF/MAPK, may modulate a cross-talk with the nucleus for gene expression regulation: ERK can enhance transcriptional activity of the VDR and non-genomic activation of PKC may stabilize VDR via phosphorylation (Wali et al., 1990; Hsieh et al., 1991; Morelli et al., 2001). Cytoplasmic signaling pathways are increasingly being recognized to regulate cell growth and differentiation as well as apoptosis. 1,25(OH) 2D and its analogous induce G0/G1 arrest and an inhibitory effect on the G1/S checkpoint of the cell cycle by upregulating p27 and p21, the cyclin dependent kinase inhibitors implicated in G1 arrest (Wang et al., 1996). Calcitriol promotes cleavage of caspase 3, polyadenyl ribose 6 phosphate (PARP), and the growth-promoting/prosurvival signaling molecule mitogenactivated protein kinase (MEK) in a caspase-dependent manner. Moreover, calcitriol significantly up-regulates the pro-apoptotic signaling molecule MEKK-1 and inhibits the phosphorylation and expression of Akt, a kinase that regulates a key cell survival pathway (Peehl et al., 1994; McGuire et al., 2001; Fleet, 2008). Indirect mechanisms include up-regulation of transforming growth factorbeta and down-regulation of the epidermal growth factor receptor. $1,25(\mathrm{OH}) 2 \mathrm{D}$ may induce apoptosis either indirectly through effects on the insulin-like growth receptor and tumor necrosis factor-alpha or more directly via the Bcl-2 family system, the ceramide pathway, the death receptors (e.g., Fas), and the stressactivated protein kinase pathways (Jun $\mathrm{N}$ terminal kinase and p38). The inhibition of tumor invasion and metastasis has been demonstrated and mechanisms involved include inhibition of serine proteinases, metalloproteinases, and angiogenesis (Seubwai

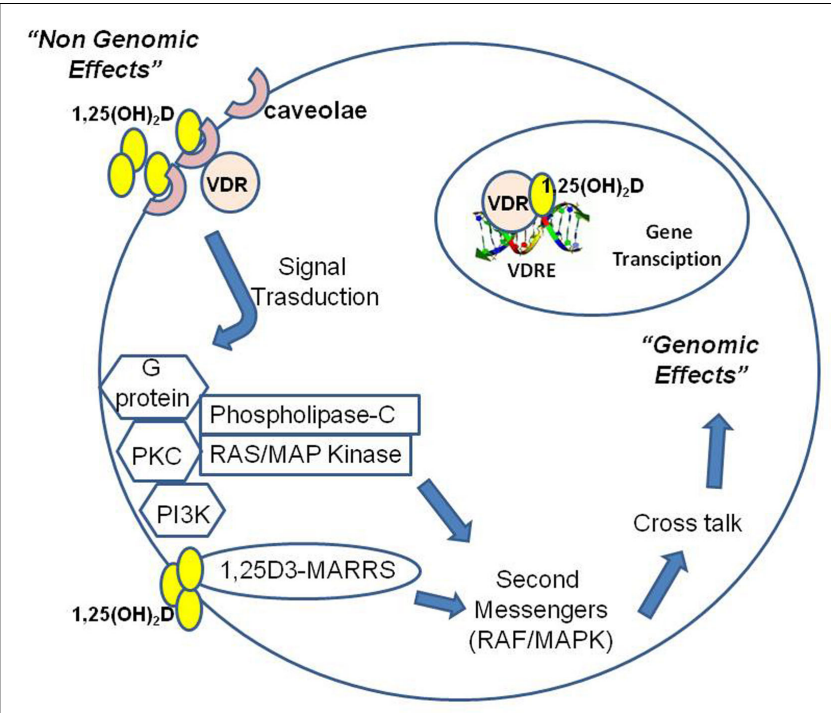

FIGURE 3 | 1,25(OH)2D operates through nuclear receptor-mediated and plasma membrane-initiated mechanisms. 1,25(OH)2D interacts with the vitamin D receptor (VDR) localized in the cell nucleus to generate genomic effects or in caveolae of the plasma membrane to generate non-genomic effects (rapid responses, RR). Moreover, 1,25(OH)2D can directly interact with a novel receptor for $1,25(\mathrm{OH}) 2 \mathrm{D}$ called 1,25D3-MARRS (membrane-associated, rapid response steroid-binding). Binding of $1,25(\mathrm{OH}) 2 \mathrm{D}$ at plasma membrane may activate one or more second messenger systems, including phospholipase $C(P K C)$, protein kinase C, G protein-coupled receptors, or phosphatidylinositol-3-kinase (PI3K). Possible outcomes include opening of the voltage-gated calcium or chloride channels or generation of second messengers. Some of these second messengers, particularly RAF/MAPK, may modulate a cross-talk with the nucleus for gene expression regulation.

et al., 2007). 1,25(OH)D inhibits the proliferation of endothelial cells in vitro and reduces angiogenesis in vivo. However, calcitriol was not able to induce apoptosis and cell cycle arrest in endothelial cells isolated from normal tissues, while these effects were observed in tumor-derived endothelial cells (Trump et al., 2010). Endothelial cell tube formation induced by vascular endothelial growth factor (VEGF) and tumor growth are inhibited in vivo by calcitriol administration to mice with VEGF-overexpressing MCF-7 xenografts (Merke et al., 1989; Mantell et al., 2000; Bernardi et al., 2002; Pendás-Franco et al., 2008; Chung et al., 2009). In squamous carcinoma cells, calcitriol promote the angiogenic factor interleukin-8 (IL-8) but in prostate cancer cells calcitriol interrupts IL-8 signaling, inducing the inhibition of endothelial cell migration and tube formation (Lin et al., 2002; Bao et al., 2006). The inhibition of prostate and lung cancer metastasis is observed in murine models treated with calcitriol: anti-angiogenic activity of calcitriol may contribute to this effect (Getzenberg et al., 1997; Nakagawa et al., 2005).

Vitamin D acts cooperatively with calcium serum levels, both pathways converge in the inhibition of Wnt/beta-catenin with the final antiproliferative effect; high levels of serum calcium modulate the metabolism of extrarenal 1,25(OH)2D encouraging higher local concentrations steady-state, $1,25(\mathrm{OH}) 2 \mathrm{D}$ also up-regulates the expression of calcium-sensitive receptors by enhancing the 
antiproliferative response to high concentrations of extracellular calcium (Holick and Chen, 2008; Peterlik et al., 2009).

Some recent data suggest that the form electively involved in cellular processes of differentiation and mitosis (non-calcemic effects), is represented by $25(\mathrm{OH}) \mathrm{D}$ (calcidiol), which occupies a lot of VDR in vivo while 1,25( $\mathrm{OH}) 2 \mathrm{D}$ (calcitriol) might be more involved in calcium homeostasis (Tuohimaa, 2008).

\section{ROLE OF VITAMIN D IN CANCER DEVELOPMENT}

Several levels of evidence support the relationship between vitamin D and cancer: (1) low circulating levels of vitamin D are associated with increased risk of developing cancer, (2) a high intake of vitamin D is associated with a reduced risk of cancer, (3) the aggressiveness of a cancer is lower in summer when the production of vitamin D is higher, (4) polymorphisms of genes encoding proteins involved in the signal pathway of vitamin $\mathrm{D}$ affect the risk of developing cancer. This relationship is supported by in vitro studies and epidemiologic studies. A lot of in vitro studies have demonstrated that exposure of tumor cells to high concentrations of vitamin D compounds inhibit their proliferation and induce differentiation. Numerous epidemiologic studies have shown the association between factors expected to reduce vitamin D levels (e.g., geography and latitude, history of sun exposure, lifestyle) and the increased rates of cancer, highlighting the protective effects of sunlight and high levels of vitamin D on various types of tumors (Ma et al., 1998; Janowsky et al., 1999; Feskanich et al., 2004; Jacobs et al., 2004; Robsahm et al., 2004; Lowe et al., 2005; Boscoe and Schymura, 2006; Ali and Vaidya, 2007). Apperly in 1941 firstly suggested that the difference in cancer incidence observed in North America at different latitudes (North-South gradient: high in the north, low in the South), was correlated with the cutaneous production of vitamin $\mathrm{D}$ in the areas with a major sun exposure (Apperly, 1941; Garland and Garland, 1980). In 1981 it was shown that $1,25(\mathrm{OH}) 2 \mathrm{D}$, in nanomolar concentrations, was able to significantly inhibit the proliferation of human melanoma cells and stimulate differentiation of myeloid leukemia cells (Wali et al., 1990; Hsieh et al., 1991; Morelli et al., 2001). Many studies have confirmed an association between low serum levels of vitamin $\mathrm{D}$ and incidence and mortality of several type of tumors such as melanoma, breast cancer, prostate, colorectal, ovarian, kidney, esophagus, stomach, non-Hodgkin's lymphoma (Grant and Garland, 2006; Pilz et al., 2008; Hutchinson et al., 2010; Grant et al., 2011). However, data about vitamin D and cancer are often conflicting, with a considerable variability.

\section{CANCER, VITAMIN D, INFLAMMATION, AND IMMUNITY}

Inflammation is implicated in the development and progression of many cancer types. Recent data have emphasized the critical role of immune and inflammatory processes in the carcinogenesis of the colon, liver, stomach, and prostate cells (Coussens and Werb, 2002; Haverkamp et al., 2008). Although the interaction between vitamin $\mathrm{D}$, inflammation, and cancer is not yet clear, the observation that VDR is expressed significantly in the immune system has raised to the possibility that vitamin $\mathrm{D}$ and its analogous may exert immunomodulatory activity (Lucia and Torkko, 2004; Narayanan et al., 2006; Trump et al., 2006; Krishnan et al., 2007). Cellular studies revealed that Vitamin D modulates the activity of various defense and immune cells including blood monocytes, macrophages, antigen-presenting cells and activated CD4 T cells, or epithelial cells (Bhalla et al., 1983; Manolagas et al., 1986; Veldman et al., 2000). It is well established that $1,25(\mathrm{OH}) 2 \mathrm{D}$ modulates $\mathrm{T}$ lymphocyte proliferation and function. The biologically active $1,25(\mathrm{OH}) 2 \mathrm{D}$ inhibits proliferation of $\mathrm{TH}$ lymphocytes and shifts the expression of cytokines from a TH1 based response toward a $\mathrm{TH} 2$ based profile. Current data suggest that $1,25-(\mathrm{OH}) 2 \mathrm{D}$ acts on the adaptive immune response by modulating the functions of dendritic cells. In addition, dendritic cells and activated T lymphocytes showed the capacity to synthesize $1,25(\mathrm{OH}) 2 \mathrm{D}$ from sunlight-derived precursors suggesting an immune autocrine/paracrine activity (Sigmundsdottir et al., 2007). Although vitamin D has no direct antimicrobial activity, there is evidence that calcitriol can modulate host response while its deficiency increases susceptibility and severity in Mycobacterium tuberculosis infection. Calcitriol in the presence of $25(\mathrm{OH}) \mathrm{D}$ raises antimicrobial activity of macrophages against $M$. tuberculosis after stimulation with mycobacterial ligands. Mycobacterial activation of toll-like receptor-2 (TLR-2) raises the expression of both VDR and CYP27B that leads to an increased conversion of $25(\mathrm{OH}) \mathrm{D}$ to $1,25(\mathrm{OH}) 2 \mathrm{D}$ and subsequent expression of the antimicrobial peptide cathelicidin via VDR (Garland et al., 2007; Colston, 2008). In addition, a recent study has shown that a single high oral dose of vitamin D3 (100,000 IU) significantly enhances the antimycobacterial immunity of tuberculosis contacts by restricting recombinant $M$. bovis in vitro (Martineau et al., 2007). Interestingly, these recent findings add credence to the historical tuberculosis treatment with sunlight and cod liver oil, in fact, more than a century ago (1849), the British physician C. J. B. Williams described a "marked and unequivocal improvement" after treatment with cod liver oil (rich in vitamin $\mathrm{D}$ ) in the treatment of tuberculosis.

\section{VDR POLYMORPHISMS}

Results from previous studies on the association of VDR polymorphisms with different cancer types are somewhat contradictory, and the role of VDR in the etiology of cancer is still equivocal. Genetic studies have investigated the possible relationship between some histotypes of cancer and the detection of specific single-nucleotide polymorphisms (SNPs) of the VDR gene (VDR SNPs) and other selected genes involved in the pathway of vitamin D such as protein gene transport of vitamin D, CYP27B1 and CYP24A1, which respectively encode the enzymes that synthesizes and degrades 1,25(OH) 2D (McCullough et al., 2009). Most studies are focused on polymorphisms of VDR, whose gene is located on chromosome 12q12-q14 (Table 1). About 200 different described SNPs VDR, VDR polymorphisms more frequently associated with tumorigenesis are: Fok1, Bsm1, Taq1, Apa1, EcoRV, $\mathrm{Cdx} 2$, although data in this area are often contradictory and yet to be clarified. The most frequently studied SNPs VDR are the restriction fragment length polymorphisms FokI and BsmI. The FokI restriction fragment length polymorphism, located in the coding region of the VDR gene, lead to the production of a VDR protein that is three amino acids longer. Although no significant differences in ligand affinity, DNA binding, or transactivation activity found between these two VDR forms, the shorter VDR variant 
Table 1 |VDR polymorphisms associated with cancer.

\begin{tabular}{ll}
\hline Cancer & VDR polymorphisms \\
\hline Prostate & Fokl, Bsml, Taq, Apal, poly (A) \\
Breast & Fokl, Bsml, Taql, Apal, poly (A) \\
Melanoma & Fokl, Bsml \\
Colorectal & Fokl, Bsml \\
Thyroid & Apal, Fokl, Taql \\
\hline
\end{tabular}

display higher potency than the longer one. The BsmI is intronic and located at the 3-end of the gene. BsmI does not alter the amount, structure, or function of the final VDR protein produced, but it is strongly linked with a poly (A) repeat and may affect VDR messenger RNA stability. The strongest associations found by a recent meta-analysis regard melanoma with BsmI and FokI; prostate cancer with BsmI, FokI, ApaI; breast cancer with BsmI, FokI, and TaqI (Chen et al., 2009; Kostner et al., 2009; Raimondi et al., 2009). In particular, in prostate cancer, the haplotype analysis showed that the allelic variants $B s m \mathrm{I}(\mathrm{B})-\mathrm{APAI}(\mathrm{A})-\mathrm{TaqI}(t)$ were associated with a higher Gleason score than allelic variants $B s m \mathrm{I}$ (b)-APAI (a)-TaqI (T). For breast cancer Lowe et al. have shown a risk of developing cancer six times higher for women with low levels of $25(\mathrm{OH}) \mathrm{D}(<20 \mathrm{ng} / \mathrm{ml})$ associated with the $B s m \mathrm{I} b b$ genotype than women with sufficient levels of 25(OH)D (>20 ng/ml) and $\mathrm{BB}$ or B $b$ genotype (Lowe et al., 2005; Chen et al., 2009). With regard to melanoma, a meta-analysis acknowledged the strongest association with the $f$ allele of the polymorphism Fok1 and the B allele of the polymorphism Bsm1 (Gandini et al., 2009). Studies of Fok1 polymorphisms in colorectal cancer have provided strongly conflicting data although it seems that the genotype $f f$ is associated with a slightly lower risk of developing this cancer compared with FF genotype; but a recent meta-analysis of all studies on colorectal cancer and VDR SNPs support the evidence of an association between $B s m \mathrm{I}$ polymorphism with a lower colorectal cancer risk risk $(\mathrm{RR}=0.57,0.36-0.89$ for $\mathrm{BB}$ versus $\mathrm{bb}$, eight studies); rather than FokI, PolyA, TaqI, Cdx2, and ApaI VDR polymorphisms (McCullough et al., 2009; Touvier et al., 2011). Regarding differentiated thyroid cancer, a study conducted in 2009 on 172 patients found the association with VDR polymorphisms FokI, TaqI, and ApaI, namely: while the alleles AA and FF of the ApaI and FokI VDR polymorphisms and the haplotype $t \mathrm{ABF}$ confer to protection from follicular carcinoma, the haplotype Tabfappeared to be associated with an increased follicular thyroid carcinoma risk: these findings need to be confirmed in studies with larger numbers of patients (Penna-Martinez et al., 2009). Furthermore, genotypes and haplotypes so-called "at risk" are influenced by environmental factors and lifestyle, such as calcium and vitamin D levels, but no study clarifies these interactions.

\section{EFFECTS OF CANCER ON VITAMIN D SYSTEM}

The attention is mainly focused on the impact that vitamin $\mathrm{D}$ has on cancer, but it is also important to understand the effects that cancer has on vitamin D system. Up-regulation of VDR expression has been shown in several tumors and is thought to represent an important endogenous response to tumor progression. Matusiak et al. (2005) showed that VDR levels were low in normal colonic epithelial cells; were increased in aberrant crypt foci, polyps, and well-differentiated tumor cells; and then declined as a function of tumor cell de-differentiation; this suggests that the progression of colon cancer can cause a reduced response to the action of vita$\min \mathrm{D}$, due to a reduced rate of this protein that translocates to the nucleus as tumors progress. Over-expression of VDR indicates a good prognosis for cholangiocarcinoma indicating an active role for VDR in mediating the antiproliferative effects of $1,25(\mathrm{OH}) 2 \mathrm{D}$ in cholangiocarcinoma cell lines. The over-expression of VDR seems to be an endogenous mechanism of response to tumor progression correlated with a better prognosis; through receptor over-expression in tumor cell lines is in fact enhanced the antiproliferative effect of vitamin D (Pelczynska et al., 2005; Seubwai et al., 2007). A reduced expression of the enzyme $25(\mathrm{OH})$ $\mathrm{D}-1 \alpha$-hydroxylase in malignant cells has also suggested but it has not been uniformly observed in all tumor types; Friedrich et al. (2006) described a major expression of the enzyme $25(\mathrm{OH}) \mathrm{D}$ $1 \alpha$-hydroxylase in breast cancer cells than in healthy breast cells. Moreover, some tumor cell lines, such as breast and colorectal cancer cells, showed an amplification of the expression of the catabolic enzyme 24-hydroxylase (Townsend et al., 2005; Beildeck and Byers, 2009). All these findings reinforce the concept that higher vitamin D levels represent a protective factor against the onset and progression of cancer.

The main tumor models taken in consideration to investigate the relationship between Vitamin D and cancer are prostate cancer, breast cancer, melanoma, colorectal cancer. Endocrine tumors also represent an interesting model because specific hormones may influence the Vitamin D pathway.

\section{VITAMIN D AND PROSTATE CANCER}

Studies investigating the role of vitamin D in prostate cancer have rapidly developed since the assumption that the deficiency of vitamin D engrave on cancer risk up to the most recent clinical trials involving the administration of vitamin $\mathrm{D}$ analogs for cancer treatment (Woo et al., 2005; Petrioli et al., 2007; Schwartz, 2009). Prostate cancer is the most common male cancer in the Western world. Both healthy and tumor prostate cells, have receptors for vitamin $\mathrm{D}$ and contain key enzymes for vitamin D metabolism. Since 1990 it was observed that the major risk factors for prostate cancer, such as advanced age, black race, residence in higher latitudes, were all associated with reduced vitamin D synthesis and inversely related to exposure to ultraviolet radiation (Schwartz and Hulka, 1990). The antiproliferative, pro-differentiating, and anti-metastatic effects of vitamin D metabolites on prostate cells have been demonstrated in vitro but are not always as obvious in vivo (Ahn et al., 2009; Gupta et al., 2009; Travis et al., 2009; Barnett et al., 2010; Gilbert et al., 2011). The mechanisms of these effects were not yet fully characterized but include inhibition of cell proliferation (cell cycle arrest), invasion (inhibition of metalloproteinases), migration, metastasis, angiogenesis (Schwartz, 2009). Limited data suggest that vitamin $\mathrm{D}$ alone has therapeutic value in prostate cancer. In a pilot study, Woo et al. showed a prolongation of PSA doubling time after cholecalciferol administration in men who had a PSA relapse after definitive therapy. In an open-label, non-randomized pilot study of calcitriol among men with early recurrent prostate cancer, authors observed that calcitriol slowed 
the rate of PSA rise compared with the pre-treatment rate. Osborn et al. reported a trial of calcitriol in patients with hormone refractory prostate cancer in which oral calcitriol was given daily. No objective responses were noted in that study, and dose escalation of oral 1,25(OH)2D was limited by hypercalcemia encountered in $30 \%$ of patients (Osborn et al., 1995; Gross et al., 1998; Woo et al., 2005). After these initial studies several authors demonstrated that intermittent, high-dose calcitriol regimens are safe and feasible (Beer et al., 2001; Morris et al., 2004; Chen and Kittaka, 2011). A shortcoming of all previous studies of vitamin D-based therapies is that calcitriol and the other analogous that were studied were used at doses well below the maximum tolerated dose (MTD). In preclinical models, both in vitro and in vivo exposure to very high concentrations of calcitriol are necessary to produce antitumor effects. Muindi et al. (2002) demonstrated that the exposure achieved in patients was only $20 \%$ to $33 \%$ of the exposure that was identified as necessary to produce activity in preclinical models. Chadha et al. showed that the highest dose of intermittent calcitriol ever given in a phase 2 trial in any disease (iv calcitriol at a dose of $74 \mu \mathrm{g}$ weekly in combination with dexamethasone) was well tolerated but failed to produce a clinical or PSA response in men with castration-resistant prostate cancer. Possible explanations include calcitriol resistance mechanisms such as loss of VDR and enhanced calcitriol degradation by CYP24 (Chadha et al., 2010).

\section{VITAMIN D AND BREAST CANCER}

Breast cancer is one of the most common female cancers in the Western population and there is a growing interest in identifying the role and the relative importance of environmental risk factors, lifestyle and diet in this type of tumor. The relationship between vitamin $\mathrm{D}$ and breast cancer is supported by laboratoristic, epidemiological, and genetic studies (Garland et al., 2007; Abbas et al., 2008; Colston, 2008; Mohr et al., 2008). Both healthy and cancer breast cells express the VDR and gene ablation studies have shown a role of VDR in physiological mammary gland development. Zinser and Welsh (2004) recently showed that after the stimulation with the carcinogen DMBA, mice knockout for VDR gene developed a higher number of pre-malignant lesions compared to wild-type mice. It is also very probable that breast cells are able to locally synthesize $1,25(\mathrm{OH}) 2 \mathrm{D}$, since both healthy cells and cancer cells express the $1 \alpha$-hydroxylase enzyme activity. The antiproliferative and pro-differentiating effects of vitamin D seems to regulate differentiation in the breast by a balance between the activity of the $1 \alpha$-hydroxylase and 24-hydroxylase enzymes, responsible respectively for the synthesis and degradation of the active hormone $1,25(\mathrm{OH}) 2 \mathrm{D}$. Several studies have found an increased expression of CYP24 in tumor cells compared to healthy cells, suggesting that the malignant tissue present a tendency to the degradation of active vitamin D (Townsend et al., 2005). In confirmation of this, several meta-analysis found an inverse correlation between circulating levels of $25(\mathrm{OH}) \mathrm{D}$ and risk of developing breast cancer, most pronounced for values of $25(\mathrm{OH}) \mathrm{D}<20 \mathrm{ng} / \mathrm{ml}$ (Abbas et al., 2008). Furthermore, an analysis of all studies focused on the relationship between breast cancer and serum levels of $25(\mathrm{OH}) \mathrm{D}$ divided into quintiles, showed among 1,760 subjects, a 50\% reduced risk of developing cancer with serum $25(\mathrm{OH}) \mathrm{D}>52 \mathrm{ng} / \mathrm{ml}$, compared to those with serum $25(\mathrm{OH}) \mathrm{D}<13 \mathrm{ng} / \mathrm{ml}$. Levels of $25(\mathrm{OH}) \mathrm{D}$
$>52 \mathrm{ng} / \mathrm{ml}$ can be achieved by oral intake of 3,000 IU/day of vitamin D analogs (equivalent to 2,000 IU/day orally in combination with exposure to sunlight for about $12 \mathrm{~min} /$ day; Garland et al., 2007). A large study of 107 countries confirmed a protective effect of UV-B irradiation on the risk of developing breast cancer, regardless of overweight, age, alcohol consumption, and other covariates (Mohr et al., 2008). There are few data regarding the relation between vitamin $\mathrm{D}$ and recurrence of breast cancer after treatment. Vrieling et al. investigated the survival in a large prospective cohort of 1,295 postmenopausal breast cancer patients in relation to post-diagnostic serum levels of $25(\mathrm{OH}) \mathrm{D}$; the study showed that lower serum calcidiol concentrations were associated with poorer overall and distant disease-free survival. A previous study, the Women's Healthy Eating and Living (WHEL) Study, evaluated the associations between circulating levels of $25(\mathrm{OH}) \mathrm{D}$ and dietary, supplemental, and total intake of vitamin $\mathrm{D}$ and recurrent or new breast cancer events: no significant associations were observed during pre and postmenopausal status for local, regional, or distant recurrence or death; although for premenopausal women was observed a significant inverse relation between dietary vitamin D intake and recurrence (Jacobs et al., 2011; Vrieling et al., 2011).

\section{VITAMIN D AND MELANOMA}

In scientific and public communities, there is an ongoing discussion on the balance between positive and negative effects of solar ultraviolet-exposure on skin cancers. The identification of an independent action of vitamin D on melanoma risk is difficult to establish given the contrasting and confounding effects of solar exposure on skin melanocytes. Both UV-A and UV-B radiation induce structural DNA-damage and is well established that sunburns are crucial in the pathogenesis of SCC, basal cell carcinoma (BCC), and malignant melanoma (MM). It is accepted that chronic sun exposure is the most important etiological factor for the development of non-melanoma skin cancer (NMSC) through tissutal and genomic alterations, oxidative stress, and pro-inflammatory actions (Egan, 2009). Data from UV-induced carcinogenesis experiments in mice showed that the first step involves acquisition of UV-induced mutations in the p53 gene by epidermal keratinocytes. On the other side, during the last years, several evidences confirmed that $1,25(\mathrm{OH}) 2 \mathrm{D}$ regulates important cellular functions, including cellular growth and regulation of apoptosis in human keratinocytes, with antioxidative, cytoprotective, and immunomodulatory effects in the skin, protecting human keratinocytes against UV-B induced cell damage. It is well recognized that the photocarcinogenesis of skin cancer is mainly due to mutations resulting from insufficient repaired DNA photoproducts. The most established DNA photoproducts caused by UV radiation are cyclobutane pyrimidine dimers (CPDs). Recent investigations show that $1,25(\mathrm{OH}) 2 \mathrm{D} 3$ reduces the number of CPDs in human keratinocytes after UV-B radiation (Lee and Youn, 1998; De Haes et al., 2004; Trémezaygues et al., 2006). Interestingly Lee et al. (2011) demonstrated that calcitriol exert anticancer effects enhancing natural killer (NK) cells susceptibility of human melanoma cells lines: 1,25(OH)2Dresistant melanoma cells treated with 1,25(OH)2D showed higher susceptibility to NK cells via heat shock protein 60 (Hsp60)mediated up-regulation of FAS expression. Melanoma cells, in 
addition to expressing the VDR, are able to synthesize $1,25(\mathrm{OH}) 2 \mathrm{D}$ from $25(\mathrm{OH}) \mathrm{D}$ and proliferate much more slowly in the presence of calcitriol. The expression of VDR and the growth inhibition induced by $1,25(\mathrm{OH}) 2 \mathrm{D}$ have been noted in human MM cell lines. It has also been demonstrated that calcitriol is able to promote apoptosis and to inhibit proliferation of human melanoma cells in vitro (Evans et al., 1996; Seifert et al., 2004). In addition, a recent study indicates a cross-talk between VDR and peroxisome proliferator-activated receptor (PPAR)-signaling pathways through 1,25(OH)2D in melanoma cell lines. Since that both VDR and PPAR-signaling pathways regulate a lot of key genes for several cellular functions including cell proliferation, cell differentiation, immune responses, and apoptosis, the provided link between VDR and PPAR may represent an important new tool for treatment and prevention of melanoma, but the physiological and pathophysiological relevance of this cross-talk remain to be clarified (Sertznig et al., 2009). Although the data available to date are insufficient to draw realistic conclusions, several studies suggest a protective role of vitamin D in melanoma: Newton-Bishop et al. have recently showed a significant reduction in the risk of disease recurrence in melanoma patients treated with vitamin $\mathrm{D}$ supplementation compared with those not treated, the frequency of relapses was reduced in particular with serum $25(\mathrm{OH}) \mathrm{D}>24 \mathrm{ng} / \mathrm{ml}$ (equivalent to $60 \mathrm{nmol} / \mathrm{l})$. In this study, higher $25(\mathrm{OH}) \mathrm{D}$ levels were associated with lower Breslow thickness at diagnosis and were independently protective of relapse and death (Newton-Bishop et al., 2009). Nürnberg also showed an association between low levels of circulating $25(\mathrm{OH}) \mathrm{D}$ and progression of melanoma, with a substantially reduced levels of $25(\mathrm{OH}) \mathrm{D}$ in patients with melanoma progression in stage IV than those in stage I. Furthermore, those patients with low $25(\mathrm{OH}) \mathrm{D}$ serum levels $(<10 \mathrm{ng} / \mathrm{ml})$ developed earlier distant metastatic disease compared to those with higher 25(OH) D serum levels ( $>20 \mathrm{ng} / \mathrm{ml}$; Nürnberg et al., 2009). A randomized placebo-controlled trial evaluated the effects of vitamin $\mathrm{D}$ combined with calcium $(\mathrm{CaD})$ supplementation on skin cancer among postmenopausal women aged 50-79 years $(N=36,282)$ enrolled into the Women's Health Initiative (WHI): vitamin $\mathrm{D}$ plus calcium $(\mathrm{CaD})$ supplementation $(1,000 \mathrm{mg}$ of elemental calcium plus $400 \mathrm{IU}$ of cholecalciferol daily) for a mean follow-up period of 7.0 years did not reduce the overall incidence of NMSC or melanoma, but in women with history of NMSC, $\mathrm{CaD}$ supplementation reduced melanoma risk (Tang et al., 2011).

\section{VITAMIN D AND COLORECTAL CANCER}

Since 1980, when a protective role of vitamin D in colorectal cancer was firstly suggested, many epidemiological studies have been developed to confirm this hypothesis. A crucial point was the observation that mortality from colorectal cancer increased with geographical latitude: the progressive decrease of levels of vitamin $\mathrm{D}$ as results of weaker UV-B radiation seen at higher latitudes was taken in account to explain the geographical pattern of cancer mortality (Garland and Garland, 1980). It is now well established that vitamin $\mathrm{D}$ and its metabolites act as inhibitors of colorectal cancer progression via several underlying mechanisms, some of which have been clarified during past few years. Vitamin D influences both the initiation and progression of colorectal cancer interacting with Wnt/beta-catenin signaling (a recognized contributor to colorectal cancer progression) and the innate immune response (; Shah et al., 2006; Byers et al., 2012).

A recent meta-analysis of longitudinal epidemiological studies evaluated the relationship between Vitamin D levels and risk of colorectal cancer: Eight studies comprising 3,556 patients were included in the analysis and support previous evidence that serum Vitamin D levels are inversely associated with risk of colorectal cancer for patients with $25(\mathrm{OH}) \mathrm{D}$ levels in the highest compared with lowest quintiles. An increase of $25(\mathrm{OH}) \mathrm{D}$ by $20 \mathrm{ng} / \mathrm{ml}$ was associated with a risk reduction of 59\% for rectal cancer and $22 \%$ for colon cancer. Analyses stratified by anatomical site suggest a stronger risk reduction for rectal cancers compared with colon cancers, however, this finding did not reach statistical significance (Yin et al., 2009). One of the largest studies to date and one of the first based on European populations showed that compared with a mid-range concentration of 50-75 nmol/l, 25(OH)D levels lower than $25 \mathrm{ng} / \mathrm{ml}(50 \mathrm{nmol} / \mathrm{l})$ were associated with an increased risk of colorectal cancer (Jenab et al., 2010). Patients with 25(OH)D levels greater than $100 \mathrm{nmol} / \mathrm{l}$ had a significant $40 \%$ lower risk of colorectal cancer than those patients with levels lower than $25 \mathrm{nmol} / \mathrm{l}$. Previous studies have also shown that low levels of vitamin $\mathrm{D}$ are associated with increased mortality and aggressiveness of colorectal cancer, while there was a significant $30 \%$ reduction in formation of colorectal adenomas among patients with higher versus lower $25(\mathrm{OH}) \mathrm{D}$ levels. These studies, together with in vitro studies demonstrating that colorectal epithelial cells express the VDR, represent the start point to hypothesize a therapeutic effect of Vitamin D in colorectal cancer and to design several therapeutic studies. However, data are conflicting: the study of the WHI (Women's Health Initiative), conducted on 36,282 women in post menopausal period for 7 years, showed no significant protective effect of supplementation with vitamin D (400 IU/day) on the development of colorectal cancer. This study had some bias: (i) a poor response to treatment among women enrolled (ii) the simultaneous intake of estrogen, which modify the effects of treatment (iii) too low doses of vitamin D (400 IU/day) to correct the deficit and to ensure an antiproliferative effect (Wactawski-Wende et al., 2006; Ding et al., 2008). A meta-analysis conducted subsequently by Gorham et al. (2007), which divided 25(OH)D concentrations into quintiles, showed a $50 \%$ reduction in the incidence of colorectal cancer with serum levels of $25(\mathrm{OH}) \mathrm{D}>32 \mathrm{ng} / \mathrm{ml}$ (Gorham et al., 2007). A recent and extensive European observational study confirmed a strong inverse relationship between $25(\mathrm{OH}) \mathrm{D}$ concentrations and risk of developing colorectal cancer: among subjects with $25(\mathrm{OH}) \mathrm{D}$ levels equal to the highest quintile the risk was reduced by $40 \%$ compared with subjects with $25(\mathrm{OH}) \mathrm{D}$ levels corresponding to the lowest quintile (Jenab et al., 2010).

\section{VITAMIN D AND ENDOCRINE TUMORS}

The pathway of vitamin $\mathrm{D}$ seems to be involved in the development of endocrine and neuroendocrine tumors too. The Pit-1 (pituitary transcription factor) is a transcription factor present in pituitary and other cells and tissues, some studies highlighted its complex relationship with the expression of VDR (Seoane et al., 2007), this close relationship may represent a Key mechanism of carcinogenesis in endocrine organs. Studies in cell cultures of 
medullary thyroid carcinoma showed contrasting effects of vitamin D: stimulatory on cell proliferation and inhibitory on the secretion of calcitonin (Baier et al., 1994), but an antiproliferative effect of calcitriol has also been showed in the same cancer histotype (Zabel et al., 2003). Regarding differentiated thyroid carcinoma cells, an over-expression of the VDR has been detected and an antiproliferative effects of vitamin D (G1 phase arrest and accumulation of p27) in a dose-dependent manner has been reported. Khadzkou et al. evaluated papillary thyroid carcinoma (PTC) specimens for VDR and 1-a-hydroxylase expression by RT-PCR and immunohistochemistry. The majority of patients showed VDR and 1-a-hydroxylase in areas of PTC, but negative staining in normal thyroid epithelium. VDR levels were significantly lower in PTC lymph node metastases than in primary tumors or matched normal tissue, even if this study did not assess vitamin D levels in patients to investigate the correlation with tumor histology (Liu et al., 2002; Khadzkou et al., 2006). A recent study investigated the effects of calcitriol on the development/progression of capsular invasive carcinomas (CICs), using a rat thyroid carcinogenesis model. It has been found that treatment with calcitriol under sulfadimethoxine (SDM)-promotion for 13 weeks reduced the multiplicity of CICs, while cell proliferation activity, estimated by the number of Ki-67-positive cells in CICs, did not differ between the SDM-alone and SDM plus calcitriol groups; the authors suggest that calcitriol targets cell proliferation inhibiting phosphoinositide 3-kinase (PI3K)/Akt signaling, controlling G1/S transition (Kemmochi et al., 2011).

Another study showed an additive and synergistic antiproliferative effects of a combination treatments of $1,25(\mathrm{OH}) 2 \mathrm{D}$ or its superagonistic analog CD578 in anaplastic thyroid cancer, in combination with paclitaxel and suberoylanilide hydroxamic acid (SAHA; Clinckspoor et al., 2011).

In murine and human insulinoma cell lines, the $1,25(\mathrm{OH}) 2 \mathrm{D}$ demonstrated to inhibit cell proliferation, induce apoptosis, upregulate VDR expression, and promote non-genomic activation of the MAPK pathway. Moreover, calcitriol significantly decreased insulin release and mRNA levels of human islets and insulinoma cells. In insulinoma cell lines, the calbindin, a protein binding calcium in a vitamin $\mathrm{D}$ dependent manner and expressed only in neuroendocrine tumors, stimulate insulin secretion. Recombinant insulin/Simian virus 40 oncogene-expressing transgenic mice treated with calcitriol showed reduced insulinoma volumes through an increased apoptosis of adenomatous cells (Pochet et al., 1989; Galbiati et al., 2002). In multiple endocrine neoplasia type 1 (MEN1), since menin can interact directly with the VDR and enhance the transcriptional activity of VDR, menin deficiency explains the low levels of VDR gene expression detected (Dreijerink et al., 2009).

In Table 2 the studies evaluating the association between vitamin $\mathrm{D}$ metabolites and cancer in humans are summarized.

\section{VITAMIN D AND CANCER PREVENTION}

The potential use of vitamin $\mathrm{D}$ and its analogs in the prevention and treatment of cancer raises a considerable scientific interest (Chen and Kittaka, 2011; Reichrath et al., 2012). According to the present paradigm, 1,25( $\mathrm{OH}) 2 \mathrm{D}$ (calcitriol) is biologically the most active hormone, whereas $25(\mathrm{OH}) \mathrm{D}$ is considered as a biologically

\begin{tabular}{llll}
\multicolumn{2}{l}{ Table 2 | Studies evaluating the association between vitamin D } \\
metabolites and cancer in humans. & & \\
\hline Reference & Cancer & Calcidiol & Calcitriol \\
\hline Ma et al. (1998) & Prostate & S & S \\
Jacobs et al. (2011) & Prostate & NS & NS \\
Barnett et al. (2010) & Prostate & S & - \\
Ahn et al. (2009) & Prostate & S & NS \\
Travis et al. (2009) & Prostate & NS & - \\
Robsahm et al. (2004) & Breast & S & - \\
Janowsky et al. (1999) & Breast & NS & S \\
Garland et al. (2007) & Breast & S & - \\
Abbas et al. (2008) & Breast & S & - \\
Mohr et al. (2008) & Breast & S & - \\
Newton-Bishop et al. (2009) & Melanoma & S & - \\
Nürnberg et al. (2009) & Melanoma & S & - \\
Robsahm et al. (2004) & Colon & S & - \\
Yin et al. (2009) & Colon & S & - \\
Jenab et al. (2010) & Colon & S & - \\
Wactawski-Wende et al. (2006) & Colon & NS & - \\
Gorham et al. (2007) & Colon & S & - \\
\hline
\end{tabular}

S, statistically significant; NS, not significant; -, not studied.

inactive prohormone activated within the cell through the action of 1a-hydroxylase (CYP27B1; Trump et al., 2004). The paradigm presents the following discrepancies: serum calcidiol concentration is a clinically valid indicator of vitamin D availability and action, whereas calcitriol concentration is not so clinically useful in clinical practice if not in specific conditions (hepatic and renal failure, hypoparathyroidism, malabsorption). The physiological concentration of calcidiol is $\sim 1,000$-fold greater than that of calcitriol, but the in vitro studies usually compare the responses at equal concentrations. The receptor appears to be mainly occupied with calcidiol in vivo and if calcidiol would be inactive, no vitamin D action could be detected. Lou et al. (2004) reported the evidence that calcidiol could be an active hormone: it was found to significantly inhibit growth of the human prostatic stromal cells at a high physiological concentration $(250 \mathrm{nM})$, whereas pharmacological (toxic) concentrations of calcitriol $(10 \mathrm{nM})$ were needed for the same effect. The vitamin D responsive gene, CYP24 (24-hydroxylase), was clearly induced by calcidiol at $250 \mathrm{nM}$ and by calcitriol at $10 \mathrm{nM}$. When using inhibitors of 24-hydroxylase, VID-400, or of 1a-hydroxylase, SDZ88-357, the effect of calcidiol was not inhibited but enhanced, suggesting calcidiol has inherent hormonal activity (Lou et al., 2004). In a more recent study with CYP27B1 mutated kidney cell line lacking 1a-hydroxylase activity, a direct evidence for the hormonal activity of calcidiol in vitro has been demonstrated. The use of the inhibitors of enzymes of vitamin D metabolism, confirmed the hormonal activity of calcidiol in several cell lines. Therefore, it can be concluded that calcidiol might be the key hormone regulating differentiation and mitotic balance and might thus be involved in the development and/or progression of chronic diseases and cancers. Calcitriol might be more involved in the regulation of intracellular and extracellular calcium balance through PTH (Tuohimaa, 2008). Therefore, in order to obtain a correct evaluation of the organic reserves of this hormone and its 
potential cytostatic effect is necessary to refer to levels of $25(\mathrm{OH}) \mathrm{D}$ (a longer half-life) other than levels of 1,25( $(\mathrm{OH}) 2 \mathrm{D}$. Significantly supraphysiological concentrations of calcitriol are required for antineoplastic effects but optimal serum concentrations $25(\mathrm{OH}) \mathrm{D}$ for cancer prevention have not been defined. For all investigated endpoints, the most advantageous serum concentrations of $25(\mathrm{OH}) \mathrm{D}$ begin at $75 \mathrm{nmol} / \mathrm{l}(30 \mathrm{ng} / \mathrm{ml})$, and the best are between 90 and $110 \mathrm{nmol} / \mathrm{l}(36-44 \mathrm{ng} / \mathrm{ml})$. Perhaps the most robust of the epidemiologic studies is that of Giovannucci et al. (2006) who developed and validated an estimate of serum $25(\mathrm{OH}) \mathrm{D}$ level and reported that among more than 40,000 individuals an increase in $25(\mathrm{OH}) \mathrm{D}$ level of $62.5 \mathrm{ng} / \mathrm{ml}$ was associated with a reduction in the risk of head/neck, esophagus, pancreas cancers, and acute leukemia by $>50 \%$. Current intake recommendations may be insufficient for important disease outcomes such as cancer, and several studies assessed the benefit of higher-dose (above current recommendations) and higher achieved 25-hydroxyvitamin D levels $[25(\mathrm{OH}) \mathrm{D}]$, although the MTD of calcitriol is unclear. Mean levels of 75-110 nmol/l were reached in most Randomized Control Trials with 1,800-4,000 IU vitamin D per day without increasing health risk. As response to treatment varies by environmental factors and starting levels of $25(\mathrm{OH}) \mathrm{D}$, testing may be warranted after at least 3 months of supplementation. The definition of vitamin $D$ deficiency is still controversial. Most agree that a $25(\mathrm{OH}) \mathrm{D}$ concentration $<50 \mathrm{nmol} / \mathrm{l}$, or $20 \mathrm{ng} / \mathrm{ml}$, is an indication of vitamin D deficiency, whereas a $25(\mathrm{OH}) \mathrm{D}$ concentration of $51-74 \mathrm{nmol} / \mathrm{l}$, or $21-29 \mathrm{ng} / \mathrm{ml}$, is considered to indicate insufficiency; concentrations $>30 \mathrm{ng} / \mathrm{ml}$ are considered to be sufficient (Beer and Myrthue, 2004; Bischoff-Ferrari et al., 2006; Holick and Chen, 2008).

\section{SUMMARY AND PERSPECTIVES}

Vitamin D metabolites exert significant antineoplastic activity in preclinical models. In clinical studies, an impact of vitamin $\mathrm{D}$ has been reported in different types of cancer. A low vitamin $\mathrm{D}$ activity is associated with an increased cancer risk and a more aggressive tumor growth, while high activity of this pathway induces antitumoral effects. In particular, serum circulating levels of $25(\mathrm{OH})$ D levels $<20 \mathrm{ng} / \mathrm{ml}$ seems to expose to the risk of developing mammary and colorectal cancer.

Genomic and non-genomic mechanisms have been described to explain the vitamin D-induced antineoplastic activity. Genomic effects are mainly responsible for direct antiproliferative responses to vitamin $\mathrm{D}$, while non-genomic effects may contribute to inhibit cell proliferation through the activation of second messengers which are able to cross-talk with genomic effects.

The immune system seems to represent a relevant target for the antineoplastic effects of vitamin D. In fact, VDR is expressed in different types of inflammatory cells and vitamin $\mathrm{D}$ is able to exert inhibitory effects on chronic inflammation and consequent immune cell proliferation, which play a central role in promoting the cancer development in colon, liver, stomach, prostate, and many other cells and tissues.

Vitamin D activity and role has been especially investigated for prostate, breast, colorectal, and skin cancer. The antiproliferative, pro-differentiating, and anti-metastatic effects of vitamin D metabolites on prostate cells have been demonstrated in vitro but are not always as obvious in vivo. In mammary gland, vitamin D activity is known to contribute to the physiological development of the gland, while low levels of circulating $25(\mathrm{OH}) \mathrm{D}$ were correlated to the risk of developing breast cancer. In breast cancer cells, CYP24A1, which promotes the degradation of $1,25(\mathrm{OH}) 2 \mathrm{D}$, is increased, so suggesting that the malignant tissue has a tendency to inactivate the vitamin $\mathrm{D}$ pathway.

It is now well established whether vitamin $\mathrm{D}$ and its metabolites act as inhibitors of colorectal cancer progression. However, it is likely that vitamin $\mathrm{D}$ influences both the initiation and progression of colorectal cancer interacting with Wnt/beta-catenin signaling and the innate immune response.

To establish the relationship between vitamin $\mathrm{D}$ and risk of melanoma is not easy and data available to date are insufficient to draw realistic conclusions. A protective role of vitamin $\mathrm{D}$ in melanoma is suggested by the evidence that the $1,25(\mathrm{OH}) 2 \mathrm{D}$ regulates cell growth and apoptosis in human keratinocytes, exerts antioxidative, cytoprotective, and immunomodulatory effects in the skin, protects human keratinocytes against UV-B-induced cell damage. A recent study showed that higher $25(\mathrm{OH}) \mathrm{D}$ levels were associated with lower Breslow thickness at diagnosis and were independently protective of relapse and death.

The pathway of vitamin D seems to be involved in the development of endocrine and neuroendocrine tumors too, but few and contrasting data are available to date. Some studies highlighted the complex relationship between Pit-1 (pituitary transcription factor), a transcription factor present in pituitary and other tissues, and VDR. Regarding differentiated thyroid carcinoma cells, an antiproliferative effects of vitamin D (G1 phase arrest and accumulation of p27) in a dose-dependent manner has been reported. In MEN1, VDR gene resulted to be scarcely expressed, probably due to menin deficiency, characteristic of the syndrome.

Vitamin D may also plays a role in the genetic predisposition to cancer development. The relationship between some tumor types and specific SNPs of the VDR gene has been investigated. About 200 different SNPs of VDR have been described. The VDR SNPs more frequently evaluated are Fok1, Bsm1, Taq1, Apa1, EcoRV, $\mathrm{Cdx} 2$. The strongest relationship was found between BsmI, FokI and melanoma, BsmI, FokI, ApaI and prostate cancer, BsmI, FokI, $T a q I$ and breast cancer. However, at now data are often contradictory and it is still not possible to achieve any conclusion about the correlation between VDR genotype and cancer occurrence.

Further studies are required to better clarify the molecular mechanisms of the antineoplastic activity of vitamin D and siteand tumor-specific expression and function of vitamin D pathway. In our opinion, one of the most intriguing aspect to explore in the next future is the role of vitamin D supplementation in the general population or in populations susceptible to specific types of tumors, in order to establish if it is protective against cancer development. It will be also interesting to explore therapeutic applications of vitamin $\mathrm{D}$ and its analogs in patients with cancer. In particular, better understanding of responsive phenotypes and specific combination with cytotoxic drugs are promising tools for the future use of vitamin D in cancer treatment.

\section{ACKNOWLEDGMENTS}

This study was partially supported by PRIN 2008 protocol 2008 LFK7J5. 


\section{REFERENCES}

Abbas, S., Linseisen, J., Slanger, T., Kropp, S., Mutschelknauss, E. J., Flesch-Janys, D., and Chang-Claude, J. (2008). Serum 25-hydroxyvitamin $\mathrm{D}$ and risk of post-menopausal breast cancer - results of a large case-control study. Carcinogenesis 29, 93-99.

Ahn, J., Albanes, D., Berndt, S. I., Peters, U., Chatterjee, N., Freedman, N. D., Abnet, C. C., Huang, W. Y., Kibel, A. S., Crawford, E. D., Weinstein, S. J., Chanock, S. J., Schatzkin, A., Hayes, R. B., and Prostate, Lung, Colorectal and Ovarian Trial Project Team. (2009). Vitamin D-related genes, serum vitamin $\mathrm{D}$ concentrations and prostate cancer risk. Carcinogenesis 30, 769-776.

Ali, M. M., and Vaidya, V. (2007). Vitamin D and cancer. J. Cancer Res. Ther. 3, 225-230.

Apperly, F. L. (1941). The relation of solar radiation to cancer mortality in North American. Cancer Res. 1, 191-195.

Baier, R., Grauer, A., Lazaretti-Castro, M., Ziegler, R., and Raue, F. (1994). Differential effects of 25hydroxyvitamin $\mathrm{D}$ on cell proliferation and calcitonin gene expression. Endocrinology 135, 2006-2011.

Bao, B. Y., Yao, J., and Lee, Y. F. (2006). 1 alpha\}, 25-dihydroxyvitamin D3 suppresses interleukin-8-mediated prostate cancer cell angiogenesis. Carcinogenesis 27, 1883-1893.

Barnett, C. M., Nielson, C. M., Shannon, J., Chan, J. M., Shikany, J. M., Bauer, D. C., Hoffman, A. R., Barrett-Connor, E., Orwoll, E., and Beer, T. M. (2010). Serum 25$\mathrm{OH}$ vitamin $\mathrm{D}$ levels and risk of developing prostate cancer in older men. Cancer Causes Control 21, 1297-1303.

Beer, T. M., Munar, M., and Henner, W. D. (2001). A phase I trial of pulse calcitriol in patients with refractory malignancies: pulse dosing permits substantial dose escalation. Cancer 91, 2431-2439.

Beer, T. M., and Myrthue, A. (2004). Calcitriol in cancer treatment: from the lab to the clinic. Mol. Cancer Ther. 3 , 373-338.

Beildeck, M. R., and Byers, S. W. (2009). Vitamin D analogues in colon cancer prevention and care. Curr. Colorectal Cancer Rep. 5, 185-196.

Bernardi, R. J., Johnson, C. S., Modzelewski, R. A., and Trump, D. L. (2002). Antiproliferative effects of 1alpha,25-dihydroxyvitamin $\mathrm{D}(3)$ and vitamin $\mathrm{D}$ analogs on tumor-derived endothelial cells. Endocrinology 143, 2508-2514.
Bhalla, A. K., Amento, E. P., Clemens, T. L., Holick, M. F., and Krane, S. M. (1983). Specific high-affinity receptors for 1,25-dihydroxyvitamin D3 in human peripheral blood mononuclear cells: presence in monocytes and induction in $\mathrm{T}$ lymphocytes following activation. J. Clin. Endocrinol. Metab. 57, 1308-1310.

Bischoff-Ferrari, H. A., Giovannucci, E., Willett, W. C., Dietrich, T., and Dawson-Huges, B. (2006). Estimation of optimal serum concentrations of 25-hydroxyvitamin D for multiple health outcomes. Am. J. Clin. Nutr. 84, 18-28.

Boscoe, F. P., and Schymura, M. J. (2006). Solar ultraviolet-B exposure and cancer incidence and mortality in the United States. BMC Cancer 10, 264-314. doi:10.1186/1471-2407-6-264

Byers, S. W., Rowlands, T., Beildeck, M., and Bong, Y. S. (2012). Mechanism of action of vitamin D and the vitamin D receptor in colorectal cancer prevention and treatment. Rev. Endocr. Metab. Disord. 13, 31-38.

Chadha, M. K., Tian, L., Mashtare, T., Payne, V., Silliman, C., Levine, E., Wong, M., Johnson, C., and Trump, D. L. (2010). Phase 2 trial of weekly intravenous 1,25 dihydroxy cholecalciferol (calcitriol) in combination with dexamethasone for castrationresistant prostate cancer. Cancer 116, 2132-2139.

Chen, L., Davey Smith, G., Evans, D. M., Cox, A., Lawlor, D. A., Donovan, J., Yuan, W., Day, I. N., Martin, R. M., Lane, A., Rodriguez, S., Davis, M., Zuccolo, L., Collin, S. M., Hamdy, F., Neal, D., and Lewis, S. J. (2009). Genetic variants in the vitamin $\mathrm{d}$ receptor are associated with advanced prostate cancer at diagnosis: findings from the prostate testing for cancer and treatment study and a systematic review. Cancer Epidemiol. Biomarkers Prev. 18, 2874-2881.

Chen, T. C., and Kittaka, A. (2011). Novel vitamin d analogs for prostate cancer therapy. ISRN Urol. 2011, 301490.

Chung, I., Han, G., Seshadri, M., Gillard, B. M., Yu, W. D., Foster, B. A., Trump, D. L., and Johnson, C. S. (2009). Role of vitamin D receptor in the antiproliferative effects of calcitriol in tumor-derived endothelial cells and tumor angiogenesis in vivo. Cancer Res. 69, 967-975.

Clinckspoor, I., Verlinden, L., Overbergh, L., Korch, C., Bouillon, R., Mathieu, C., Verstuyf, A., and Decallonne, B. (2011).
1,25-Dihydroxyvitamin D3 and a superagonistic analog in combination with paclitaxel or suberoylanilide hydroxamic acid have potent antiproliferative effects on anaplastic thyroid cancer. J. Steroid Biochem. Mol. Biol. 124, 1-9.

Colston, K. W. (2008). Vitamin D and breast cancer risk. Best Pract. Res. Clin. Endocrinol. Metab. 22, 587-599.

Coussens, L. M., and Werb, Z. (2002). Inflammation and cancer. Nature 420, 860-867.

Cross, H. S. (2007). Extrarenal vitamin D hydroxylase expression and activity in normal and malignant cells: modification of expression by epigenetic mechanisms and dietary substances. Nutr. Rev. 65(8 Pt 2), S108-S112.

De Haes, P., Garmyn, M., Verstuyf, A., De Clercq, P., Vandewalle, M., Vantieghem, K., Degreef, H., Bouillon, R., and Segaert, S. (2004). Two 14-epi analogues of 1, 25-dihydroxyvitamin D3 protect human keratinocytes against the effects of UVB. Arch. Dermatol. Res. 295, 527-534

Deeb, K. K., Trump, D. L., and Johnson, C. S. (2007). Vitamin D signalling pathways in cancer: potential for anticancer therapeutics. Nat. Rev. Cancer 7, 684-700.

Ding, E. L., Mehta, S., Fawzi, W. W., and Giovannucci, E. L. (2008). Interaction of estrogen therapy with calcium and vitamin D supplementation on colorectal cancer risk: reanalysis of Women's Health Initiative randomized trial. Int. J. Cancer 122, 1690-1694.

Dreijerink, K. M., Varier, R. A., van Nuland, R., Broekhuizen, R., Valk, G. D., van der Wal, J. E., Lips, C. J., Kummer, J. A., and Timmers, H. T. (2009). Regulation of vitamin D receptor function in MEN1-related parathyroid adenomas. Mol. Cell. Endocrinol. 313, 1-8.

Egan, K. M. (2009). Vitamin D and melanoma. Ann. Epidemiol. 19, 455-461.

Evans, R. M. (1988). The steroid and thyroid hormone receptor superfamily. Science 240, 889-895.

Evans, S. R., Houghton, A. M., Schumaker, L., Brenner, R. V., Buras, R. R., Davoodi, F., Nauta, R. J., and Shabahang, M. (1996). Vitamin $\mathrm{D}$ receptor and growth inhibition by 1,25-dihydroxyvitamin D3 in human malignant melanoma cell lines. J. Surg. Res. 61, 127-133.

Feskanich, D., Ma, J., Fuchs, C. S. Kirkner, G. J., Hankinson, S. E., Hollis, B. W., and Giovannucci, E. L.
(2004). Plasma vitamin D metabolites and risk of colorectal cancer in women. Cancer Epidemiol. Biomarkers Prev. 13, 1502-1508.

Fleet, J. C. (2008). Molecular actions of vitamin D contributing to cancer prevention. Mol. Aspects Med. 29, 388-396.

Friedrich, M., Diesing, D., Cordes, T., Fischer, D., Becker, S., Chen, T. C., Flanagan, J. N., Tangpricha, V., Gherson, I., Holick, M. F., and Reichrath, J. (2006). Analysis of 25-hydroxyvitamin D3-1alphahydroxylase in normal and malignant breast tissue. Anticancer Res. 26, 2615-2620.

Galbiati, F., Polastri, L., Gregori, S., Freschi, M., Casorati, M., Cavallaro, U., Fiorina, P., Bertuzzi, F., Zerbi, A., Pozza, G., Adorini, L., Folli, F., Christofori, G., and Davalli, A. M. (2002). Antitumorigenic and antiinsulinogenic effects of calcitriol on insulinoma cells and solid betacell tumors. Endocrinology 143, 4018-4030.

Gandini, S., Raimondi, S., Gnagnarella, P., Doré, J. F., Maisonneuve, P., and Testori, A. (2009). Vitamin D and skin cancer: a meta-analysis. Eur. J. Cancer 45, 634-641.

Garland, C. F., and Garland, F. C. (1980). Do sunlight and vitamin $\mathrm{D}$ reduce the likelihood of colon cancer? Int. J. Epidemiol. 9, 227-231.

Garland, C. F., Gorham, E. D., Mohr, S. B., Grant, W. B., Giovannucci, E. L., Lipkin, M., Newmark, H., Holick, M. F., and Garland, F. C. (2007). Vitamin $\mathrm{D}$ and prevention of breast cancer: pooled analysis. J. Steroid Biochem. Mol. Biol. 103, 708-711.

Getzenberg, R. H., Light, B. W., Lapco, P. E., Konety, B. R., Nangia, A. K., Acierno, J. S., Dhir, R., Shurin, Z., Day, R. S., Trump, D. L., and Johnson, C. S. (1997). Vitamin D inhibition of prostate adenocarcinoma growth and metastasis in the Dunning rat prostate model system. Urology 50, 999-1006.

Gilbert, R., Martin, R. M., Beynon, R., Harris, R., Savovic, J., Zuccolo, L., Bekkering, G. E., Fraser, W. D., Sterne, J. A., and Metcalfe, C. (2011). Associations of circulating and dietary vitamin $\mathrm{D}$ with prostate cancer risk: a systematic review and dose-response meta-analysis. Cancer Causes Control 22, 319-340.

Giovannucci, E., Liu, Y., Rimm, E. B., Hollis, B. W., Fuchs, C. S., Stampfer, M. J., and Willett, W. C. (2006). Prospective study of predictors of vitamin $\mathrm{D}$ status and cancer incidence and mortality in men. J. Natl. Cancer Inst. 98, 451-459. 
Gorham, E. D., Garland, C. F., Garland, F. C., Grant, W. B., Mohr, S. B., Lipkin, M., Newmark, H. L., Giovannucci, E., Wei, M., and Holick, M. F. (2007). Optimal vitamin D status for colorectal cancer prevention: a quantitative meta analysis. Am. J. Prev. Med. 32, 210-216.

Grant, W. B., and Garland, C. F. (2006). The association of solar ultraviolet B (UVB) with reducing risk of cancer: multifactorial ecologic analysis of geografic variation in age adjusted cancer mortality rates. Anticancer Res. 26, 2687-2699.

Grant, W. B., Juzeniene, A., and Moan, J. E. (2011). Review Article: health benefit of increased serum 25(OH)D levels from oral intake and ultraviolet- $B$ irradiance in the Nordic countries. Scand. J. Public Health 39, 70-78.

Gross, C., Stamey, T., Hancock, S., and Feldman, D. (1998). Treatment of early recurrent prostate cancer with 1,25-dihydroxyvitamin D3 (calcitriol). J. Urol. 159, 2035-2039.

Gupta, D., Lammersfeld, C. A., Trukova, K., and Lis, C. G. (2009). Vitamin D and prostate cancer risk: a review of the epidemiological literature. Prostate Cancer Prostatic Dis. $12,215-226$

Haussler, M. R., Whitfield, G. K., Haussler, C. A., Hsieh, J. C., Thompson, P. D., Selznick, S. H., Dominguez, C. E., and Jurutka, P. W. (1998). The nuclear vitamin $\mathrm{D}$ receptor: biological and molecular regulatory properties revealed. J. Bone Miner. Res. 13, 325-349.

Haverkamp, J., Charbonneau, B., and Ratliff, T. L. (2008). Prostate inflammation and its potential impact on prostate cancer: a current review. J. Cell. Biochem. 103, 1344-1353.

Holick, M. F., and Chen, T. C. (2008). Vitamin d deficiency: a worldwide problem with health consequences. Am. J. Clin. Nutr. 87, 1080S-1086S.

Hsieh, J. C., Jurutka, P. W., Galligan, M. A., Terpening, C. M., Haussler, C. A., Samuels, D. S., Shimizu, Y., Shimizu, N., and Haussler, M. R. (1991). Human vitamin D receptor is selectively phosphorylated by protein kinase $\mathrm{C}$ on serine 51 , a residue crucial to its trans-activation function. Proc. Natl. Acad. Sci. U.S.A. 88, 9315-9319.

Hutchinson, M. S., Grimnes, G., Joakimsen, R. M., Figenschau, Y., and Jorde, R. (2010). Low serum 25 hydroxyvitamin D levels are associated with increased all-cause mortality risk in a general population: the Tromsø study. Eur. J. Endocrinol. 162, 935-942.
Jacobs, E. T., Giuliano, A. R., Martinez, M. E., Hollis, B. W., Reid, M. E., and Marshall, J. R. (2004). Plasma levels of 25-hydroxyvitamin D, 1,25dihydroxyvitamin D and the risk of prostate cancer. J. Steroid Biochem. Mol. Biol. 89-90, 533-537.

Jacobs, E. T., Thomson, C. A., Flatt, S. W., Al-Delaimy, W. K., Hibler, E. A., Jones, L. A., Leroy, E. C., Newman, V. A., Parker, B. A., Rock, C. L., and Pierce, J. P. (2011). Vitamin D and breast cancer recurrence in the Women's Healthy Eating and Living (WHEL) Study. Am. J. Clin. Nutr. 93, 108-117.

Janowsky, E. C., Lester, G. E., Weinberg, C. R., Millikan, R. C., Schildkraut, J. M., Garrett, P. A., and Hulka, B. S. (1999). Association between low levels of 1,25 dihydroxyvitamin D and breast cancer risk. Public Health Nutr. 2, 283-291.

Jenab, M., Bueno-de-Mesquita, H. B., Ferrari, P., van Duijnhoven, F. J., Norat, T., Pischon, T., Jansen, E. H., Slimani, N., Byrnes, G., Rinaldi, S., Tjønneland, A., Olsen, A., Overvad, K., Boutron-Ruault, M. C., ClavelChapelon, F., Morois, S., Kaaks, R., Linseisen, J., Boeing, H., Bergmann, M. M., Trichopoulou, A., Misirli, G., Trichopoulos, D., Berrino, F., Vineis, P., Panico, S., Palli, D., Tumino, R., Ros, M. M., van Gils, C. H., Peeters, P. H., Brustad, M., Lund, E., Tormo, M. J., Ardanaz, E., Rodríguez, L., Sánchez, M. J., Dorronsoro, M., Gonzalez, C. A., Hallmans, G., Palmqvist, R., Roddam, A., Key, T. J., Khaw, K. T., Autier, P., Hainaut, P., and Riboli, E. (2010). Association between pre-diagnostic circulating vitamin $\mathrm{D}$ concentration and risk of colorectal cancer in European populations:a nested case-control study. BMJ 340, b5500.

Kemmochi, S., Fujimoto, H., Woo, G. H., Hirose, M., Nishikawa, A., Mitsumori, K., and Shibutani, M. (2011). Preventive effects of calcitriol on the development of capsular invasive carcinomas in a rat twostage thyroid carcinogenesis model. J. Vet. Med. Sci. 73, 655-664.

Khadzkou, K., Buchwald, P., Westin, G., Dralle, H., Akerström, G., and Hellman, P. (2006). 25 hydroxyvitamin D3 1alpha-hydroxylase and vitamin $\mathrm{D}$ receptor expression in papillary thyroid carcinoma. J. Histochem. Cytochem. 54, 355-361.

Kostner, K., Denzer, N., Muller, C. S., Klein, R., Tilgen, W., and Reichrath, J. (2009). The relevance of vitamin D receptor (VDR) gene polymorphism for cancer: a review of the literature. Anticancer Res. 29, 3511-3536.
Krishnan, A. V., Moreno, J., Nonn, L., Swami, S., Peehl, D. M., and Feldman, D. (2007). Calcitriol as a chemopreventive and therapeutic agent in prostate cancer: role of antiinflammatory activity. J. Bone Miner. Res. 22(Suppl. 2), V74-V80.

Lee, J. H., Park, S., Cheon, S., Lee, J. H., Kim, S., Hur, D. Y., Kim, T. S., Yoon, S. R., Yang, Y., Bang, S. I., Park, H., Lee, H. T., and Cho, D. (2011). 1,25-Dihydroxyvitamin $\mathrm{D}(3)$ enhances NK susceptibility of human melanoma cells via Hsp60mediated FAS expression. Eur. J. Immunol. 41, 2937-2946.

Lee, J. H., and Youn, J. I. (1998). The photoprotective effect of 1, 25Dihydroxyvitamin D3 on ultraviolet $\mathrm{B}$-induced damage in keratinocyte and its mechanisms of action. $J$. Dermatol. Sci. 18, 11-18.

Lin, R., Nagai, Y., Sladek, R., Bastien, Y., Ho, J., Petrecca, K., Sotiropoulou, G., Diamandis, E. P., Hudson, T. J., and White, J. H. (2002). Expression profiling in squamous carcinoma cells reveals pleiotropic effects of vitamin D3 analog EB1089 signaling on cell proliferation, differentiation, and immune system regulation. $\mathrm{Mol}$. Endocrinol. 16, 1243-1256.

Liu, W., Asa, S. L., Fantus, I. G., Walfish, P. G., and Ezzat, S. (2002). Vitamin D arrests thyroid carcinoma cell growth and induces p27 dephosphorylation and accumulation through PTEN/akt-dependent and -independent pathways. Am. J. Pathol. 160, 511-519.

Lou, Y. R., Laaksi, I., Syvälä, H., Bläuer, M., Tammela, T. L., Ylikomi, T., and Tuohimaa, P. (2004). 25Hydroxyvitamin D3 is an active hormone in human primary prostatic stromal cells. FASEB J. 18, 332-334.

Lowe, L. C., Guy, M., Mansi, J. L., Peckitt, C., Bliss, J., Wilson, R. G., and Colston, K. W. (2005). Plasma 25-hydroxy vitamin D concentrations, vitamin D receptor genotype and breast cancer risk in a UK Caucasian population. Eur. J. Cancer 41, 1164-1169.

Lucia, M. S., and Torkko, K. C. (2004). Inflammation as a target for prostate cancer chemoprevention: pathological and laboratory rationale. J. Urol. 171, S30-S34.

Ma, J., Stampfer, M. J., Gann, P. H., Hough, H. L., Giovannucci, E., Kelsey, K. T., Hennekens, C. H., and Hunter, D. J. (1998). Vitamin $\mathrm{D}$ receptor polymorphisms, circulating vitamin $\mathrm{D}$ metabolites, and risk of prostate cancer in United States physicians. Cancer Epidemiol. Biomarkers Prev. 7, 385-390.
Manolagas, S. C., Werntz, D. A., Tsoukas, C. D., Provvedini, D. M., and Vaughan, J. H. (1986). 1,25Dihydroxyvitamin D3 receptors in lymphocytes from patients with rheumatoid arthritis. J. Lab. Clin. Med. 108, 596-600.

Mantell, D. J., Owens, P. E., Bundred, N. J., Mawer, E. B., and Canfield, A. E. (2000). 1 alpha,25dihydroxyvitamin $\mathrm{D}(3)$ inhibits angiogenesis in vitro and in vivo. Circ. Res. 87, 214-220.

Martineau, A. R., Wilkinson, K. A., Newton, S. M., Floto, R. A., Norman, A. W., Skolimowska, K., Davidson, R. N., Sørensen, O. E., Kampmann, B., Griffiths, C. J., and Wilkinson, R. J. (2007). IFN-gamma- and TNFindependent vitamin D-inducible human suppression of mycobacteria: the role of cathelicidin LL-37. J. Immunol. 178, 7190-7198.

Matusiak, D., Murillo, G., Carroll, R. E., Mehta, R. G., and Benya, R. V. (2005). Expression of vitamin $\mathrm{D}$ receptor and 25-hydroxyvitamin D3-1\{alpha\}-hydroxylase in normal and malignant human colon. Cancer Epidemiol. Biomarkers Prev. 14, 2370-2376.

McCullough, M. L., Bostick, R. M., and Mayo, T. L. (2009). Vitamin D gene pathway polymorphisms and risk of colorectal, breast, and prostate cancer. Annu. Rev. Nutr. 29, 111-132.

McGuire, T. F., Trump, D. L., and Johnson, C. S. (2001). Vitamin D3induced apoptosis of murine squamous cell carcinoma cells: selective induction of caspase-dependent MEK cleavage and up-regulation of MEKK-1. J. Biol. Chem. 276, 26365-26373.

Merke, J., Milde, P., Lewicka, S., Hügel, U., Klaus, G., Mangelsdorf, D. J., Haussler, M. R., Rauterberg, E. W., and Ritz, E. (1989). Identification and regulation of 1,25-dihydroxyvitamin D3 receptor activity and biosynthesis of 1,25dihydroxyvitamin D3. Studies in cultured bovine aortic endothelial cells and human dermal capillaries. J. Clin. Invest. 83, 1903-1915.

Mohr, S. B., Garland, C. F., Gorham, E. D., Grant, W. B., and Garland, F. C. (2008). Relationship between low ultraviolet $\mathrm{B}$ irradiance and higher breast cancer risk in 107 countries. Breast J. 14, 255-260.

Morelli, S., Buitrago, C., Boland, R., and de Boland, A. R. (2001). The stimulation of MAP kinase by $1,25(\mathrm{OH})(2)$ vitamin $\mathrm{D}(3)$ in skeletal muscle cells is mediated by protein kinase $\mathrm{C}$ and calcium. Mol. Cell. Endocrinol. 173, 41-52. 
Morris, M. J., Smaletz, O., Solit, D., Kelly, W. K., Slovin, S., Flombaum, C., Curley, T., Delacruz, A., Schwartz, L., Fleisher, M., Zhu, A., Diani, M., Fallon, M., and Scher, H. I. (2004). High-dose calcitriol, zoledronate, and dexamethasone for the treatment of progressive prostate carcinoma. Cancer 100, 1868-1875.

Muindi, J. R., Peng, Y., Potter, D. M, Hershberger, P. A., Tauch, J. S., Capozzoli, M. J., Egorin, M. J., Johnson, C. S., and Trump, D. L. (2002). Pharmacokinetics of highdose oral calcitriol: results from a phase 1 trial of calcitriol and paclitaxel. Clin. Pharmacol. Ther. 72, 648-659.

Nakagawa, K., Kawaura, A., Kato, S., Takeda, E., and Okano, T. (2005). 1 alpha,25-Dihydroxyvitamin $\mathrm{D}(3)$ is a preventive factor in the metastasis of lung cancer. Carcinogenesis 26, 429-440.

Narayanan, B. A., Narayanan, N. K., Davis, L., and Nargi, D. (2006). RNA interference-mediated cyclooxygenase- 2 inhibition prevents prostate cancer cell growth and induces differentiation: modulation of neuronal protein synaptophysin, cyclin D1, and androgen receptor. Mol. Cancer Ther. 5, 1117-1125.

Nemere, I., Farach-Carson, M. C., Rohe, B., Sterling, T. M., Norman, A. W., Boyan, B. D., and Safford, S. E. (2004). Ribozyme knockdown functionally links a $1,25(\mathrm{OH}) 2 \mathrm{D} 3 \mathrm{mem}-$ brane binding protein (1,25D3MARRS) and phosphate uptake in intestinal cells. Proc. Natl. Acad. Sci. U.S.A. 101, 7392-7397.

Newton-Bishop, J. A., Beswick, S., Randerson-Moor, J., Chang, Y. M., Affleck, P., Elliott, F., Chan, M., Leake, S., Karpavicius, B., Haynes, S., Kukalizch, K., Whitaker, L., Jackson, S., Gerry, E., Nolan, C., Bertram, C., Marsden, J., Elder, D. E., Barrett, J. H., and Bishop, D. T. (2009). Serum 25-hydroxyvitamin D3 levels are associated with breslow thickness at presentation and survival from melanoma. J. Clin. Oncol. 27, 5439-5444.

Norman, A. W. (1998). Sunlight, season, skin pigmentation, vitamin $\mathrm{D}$ and 25-hydroxyvitamin D: integral components of the vitamin D endocrine system. Am. J. Clin. Nutr. 67, 1108-1110.

Norman, A. W. (2006). Vitamin D receptor: new assignments for an already busy receptor. Endocrinology 147, 5542-5548.

Nürnberg, B., Gräber, S., Gärtner, B., Geisel, J., Pföhler, C., Schadendorf, D., Tilgen, W., and Reichrath,
J. (2009). Reduced serum 25hydroxyvitamin D levels in stage IV melanoma patients. Anticancer Res. 29, 3669-3674.

Osborn, J. L., Schwartz, G. G., Smith, D. C., Bahnson, R., Day, R., and Trump, D. L. (1995). Phase II trial of oral 1,25-dihydroxyvitamin $\mathrm{D}$ (calcitriol) in hormone refractory prostate cancer. Urol. Oncol. 1, 195-198.

Peehl, D. M., Skowronski, R. J., Leung, G. K., Wong, S. T., Stamey, T. A., and Feldman, D. (1994). Antiproliferative effects of 1,25-dihydroxyvitamin D3 on primary cultures of human prostatic cells. Cancer Res. 54, 805-810.

Pelczynska, M., Wietrzyk, J., Jaroszewicz, I., Nevozhay, D., Switalska, M., Kutner, A., Zabel, M., and Opolski, A. (2005). Correlation between VDR expression and antiproliferative activity of vitamin D3 compounds in combination with cytostatics. Anticancer Res. 25, 2235-2240.

Pendás-Franco, N., García, J. M., Peña, C., Valle, N., Pálmer, H. G., Heinäniemi, M., Carlberg, C., Jiménez, B., Bonilla, F., Muñoz, A., and González-Sancho, J. M. (2008). DICKKOPF-4 is induced by TCF/beta-catenin and upregulated in human colon cancer, promotes tumour cell invasion and angiogenesis and is repressed by lalpha,25dihydroxyvitamin D3. Oncogene 27, 4467-4477.

Penna-Martinez, M., Ramos-Lopez, E., Stern, J., Hinsc, N., Hansmann, M. L., Selkinski, I., Grünwald, F., Vorländer, C., Wahl, R. A., Bechstein, W. O., Zeuzem, S., Holzer, K., and Badenhoop, K. (2009). Vitamin D receptor polymorphisms in differentiated thyroid carcinoma. Thyroid 19, 623-628.

Peterlik, M., Grant, W. B., and Cross, H. S. (2009). Calcium, vitamin D and cancer. Anticancer Res. 29, 3687-3698.

Petrioli, R., Pascuccu, A., Francinin, E., Marsili, S., Sciandiviasci, A., De Rubertis, G., Barbanti, G., Manganelli, A., Salvestrini, F., and Francini, G. (2007). Weekly highdose calcitriol and docetaxel in patients with metastatic hormonerefractory prostate cancer previously exposed to docetaxel. BJU Int. 100, 775-779.

Pilz, S., Dobnig, H., Winklhofer-Roob, B., Riedmuller, G., Fischer, J. E., and Seelhorst, U. (2008). Low serum levels of 25-hydroxyvitamin $D$ predict fatal cancer in patients referred to coronary angiography.
Cancer Epidemiol. Biomarkers Prev. 17, 1228-1233.

Pochet, R., Blachier, F., Lawson, D. E., and Malaisse, W. J. (1989). Presence of calbindin-D $28 \mathrm{~K}$ in endocrine pancreatic tumoral cells of the RINm5F line. Int. J. Pancreatol. 5, 295-304.

Raimondi, S., Johansson, H., Maisonneuve, P., and Gandini, S. (2009). Review and meta-analysis on vitamin D receptor polymorphism and cancer risk. Carcinogenesis 30 , 1170-1180.

Reichekl, H., Koeffler, H. P., and Norman, A. W. (1989). The role of vitamin $\mathrm{D}$ endocrine system in health and disease. N. Engl. J. Med. 320, 980-991.

Reichrath, J., Friedrich, M., and Vogt, T. (2012). Vitamin D and its analogs in cancer prevention and therapy. Anticancer Res. 32, 209-210.

Robsahm, T. E., Tretli, S., Dahlback, A., and Moan, J. (2004). Vitamin D3 from sunlight may improve the prognosis of breast, colon and prostate cancer (Norway). Cancer Causes Control 15, 149-158.

Schwartz, G. G. (2009). Vitamin D and intervention trials in prostate cancer: from theory to therapy. Ann Epidemiol 19, 96-102.

Schwartz, G. G., Eads, D., Rao, A., Cramer, S. D., Willingham, M. C., Chen, T. C., Jamieson, D. P., Wang, L., Burnstein, K. L., Holick, M. F., and Koumenis, C. (2004). Pancreatic cancer cells express 25-hydroxyvitamin D-1 alpha-hydroxylase and their proliferation is inhibited by the prohormone 25-hydroxyvitamin D3. Carcinogenesis 25, 1015-1026.

Schwartz, G. G., and Hulka, B. S. (1990). Is vitamin $\mathrm{D}$ deficiency a risk factor for prostate cancer? (Hypothesis). Anticancer Res. 10, 1307-1311.

Seifert, M., Rech, M., Meineke, V., Tilgen, W., and Reichrath, J. (2004). Differential biological effects of 1,25-dihydroxyVitamin D3 on melanoma cell lines in vitro. $J$ Steroid Biochem. Mol. Biol. 89-90, 375-379.

Seoane, S., Ben, I., Centeno, V., and Perez-Fernandez, R. (2007). Cellular expression levels of the vitamin $\mathrm{D}$ receptor are critical to its transcriptional regulation by the pituitary transcription factor Pit-1. Mol. Endocrinol. 21, 1513-1525.

Sertznig, P., Seifert, M., Tilgen, W., and Reichrath, J. (2009). Activation of vitamin D receptor (VDR)- and peroxisome proliferator-activated receptor (PPAR)-signaling pathways through $1,25(\mathrm{OH})(2) \mathrm{D}(3)$ in melanoma cell lines and other skin-derived cell lines. Dermatoendocrinol. 1, 232-238.

Seubwai, W., Wongkham, C., Puapairoj, A., Khuntikeo, N., and Wongkham, S. (2007). Overexpression of vitamin D receptor indicates a good prognosis for cholangiocarcinoma: implications for therapeutics. Cancer 109, 2497-2505.

Shah, S., Islam, M. N., Dakshanamurthy, S., Rizvi, I., Rao, M., Herrell, R., Zinser, G., Valrance, M., Aranda, A., Moras, D., Norman, A., Welsh, J., and Byers, S. W. (2006). The molecular basis of vitamin D receptor and betacatenin crossregulation. Mol. Cell 21, 799-809.

Sigmundsdottir, H., Pan, J., Debes, G. F., Alt, C., Habtezion, A., Soler, D., and Butcher, E. C. (2007). DCs metabolize sunlight-induced vitamin D3 to "program" $\mathrm{T}$ cell attraction to the epidermal chemokine CCL27. Nat. Immunol. 8, 285-293.

Tang, J. Y., Fu, T., Leblanc, E., Manson, J. E., Feldman, D., Linos, E., Vitolins, M. Z., Zeitouni, N. C., Larson, J., and Stefanick, M. L. (2011). Calcium plus vitamin D supplementation and the risk of nonmelanoma and melanoma skin cancer: post hoc analyses of the women's health initiative randomized controlled trial. J. Clin. Oncol. 29, 3078-3084.

Touvier, M., Chan, D. S., Lau, R., Aune, D., Vieira, R., Greenwood, D. C., Kampman, E., Riboli, E., Hercberg, S., and Norat, T. (2011) Meta-analyses of vitamin D intake, 25-hydroxyvitamin D status, vitamin D receptor polymorphisms, and colorectal cancer risk. Cancer Epidemiol. Biomarkers Prev. 20, 1003-1016.

Townsend, K., Evans, K. N., Campbell, M. J., Colston, K. W., Adams, J. S., and Hewison, M. (2005). Biological actions of extra-renal 25-hydroxyvitamin D-1alphahydroxylase and implications for chemoprevention and treatment. J. Steroid Biochem. Mol. Biol. 97, 103-109.

Travis, R. C., Crowe, F. L., Allen, N. E., Appleby, P. N., Roddam, A. W., Tjønneland, A., Olsen, A., Linseisen, J., Kaaks, R., Boeing, H., Kröger, J., Trichopoulou, A., Dilis, V., Trichopoulos, D., Vineis, P., Palli, D., Tumino, R., Sieri, S., Bueno-de-Mesquita, H. B., van Duijnhoven, F. J., Chirlaque, M. D., Barricarte, A., Larrañaga, N., González, C. A., Argüelles, M. V., Sánchez, M. J., Stattin, P., Hallmans, G., Khaw, K. T., Bingham, S., Rinaldi, S., Slimani, N., Jenab, M., Riboli, E. and Key, T. J. (2009). Serum vitamin 
$\mathrm{D}$ and risk of prostate cancer in a case control analysis nested within the European Prospective Investigation into Cancer and Nutrition (EPIC). Am. J. Epidemiol. 169, 1223-1232.

Trémezaygues, L., Sticherling, M., Pföhler, C., Friedrich, M., Meineke, V., Seifert, M., Tilgen, W., and Reichrath, J. (2006). Cutaneous photosynthesis of vitamin D: an evolutionary highly-conserved endocrine system that protects against environmental hazards including UVradiation and microbial infections. Anticancer Res. 26, 2743-2748.

Trump, D. L., Deeb, K. K., and Johnson, C. S. (2010). Vitamin D: considerations in the continued development as an agent for cancer prevention and therapy. Cancer J. 16, 1-9.

Trump, D. L., Hershberger, P. A., Bernardi, R. J., Ahmed, S., Muindi, J., Fakih, M., Yu, W. D., and Johnson, C. S. (2004). Anti-tumor activity of calcitriol: pre-clinical and clinical studies. J. Steroid Biochem. Mol. Biol. 89-90, 519-526.

Trump, D. L., Potter, D. M., Muindi, J., Brufsky, A., and Johnson, C. S. (2006). Phase II trial of highdose, intermittent calcitriol $(1,25$ dihydroxyvitamin D3) and dexamethasone in androgen-independent prostate cancer. Cancer 106, 2136-2142.

Tuohimaa, P. (2008). Vitamin D, aging, and cancer. Nutr. Rev. 66(Suppl. 2), S147-S152.

Uhmann, A., Niemann, H., Lammering, B., Henkel, C., Hess, I., Nitzki,
F., Fritsch, A., Prüfer, N., Rosenberger, A., Dullin, C., Schraepler, A. Reifenberger, J., Schweyer, S., Pietsch, T., Strutz, F., Schulz-Schaeffer, W., and Hahn, H. (2011). Antitumoral effects of calcitriol in basal cell carcinomas involve inhibition of hedgehog signaling and induction of vitamin D receptor signaling and differentiation. Mol. Cancer Ther. 10, 2179-2188.

Veldman, C. M., Cantorna, M. T., and DeLuca, H. F. (2000). Expression of 1,25-dihydroxyvitamin $\mathrm{D}(3)$ receptor in the immune system. Arch. Biochem. Biophys. 374, 334-338.

Vrieling, A., Hein, R., Abbas, S., Schneeweiss, A., Flesch-Janys, D., and Chang-Claude, J. (2011). Serum 25-hydroxyvitamin D and postmenopausal breast cancer survival: a prospective patient cohort study. Breast Cancer Res. 13, R74.

Wactawski-Wende, J., Kotchen, J. M., Anderson, G. L., Assaf, A. R., Brunner, R. L., O’Sullivan, M. J., Margolis, K. L., Ockene, J. K., Phillips, L., Pottern, L., Prentice, R. L., Robbins, J., Rohan, T. E., Sarto, G. E., Sharma, S., Stefanick, M. L., Van Horn, L., Wallace, R. B., Whitlock, E., Bassford, T., Beresford, S. A., Black, H. R., Bonds, D. E., Brzyski, R. G., Caan, B., Chlebowski, R. T., Cochrane, B., Garland, C., Gass, M., Hays, J., Heiss, G., Hendrix, S. L., Howard, B. V., Hsia, J., Hubbell, F. A., Jackson, R. D., Johnson, K. C., Judd, H., Kooperberg, C. L., Kuller, L. H., LaCroix, A. Z., Lane, D. S., Langer, R. D., Lasser,
N. L., Lewis, C. E., Limacher, M. C., and Manson, J. E. (2006). Women's Health Initiative Investigators. Calcium plus vitamin D supplementation and the risk of colorectal cancer. N. Engl. J. Med. 354, 684-696.

Wali, R. K., Baum, C. L., Sitrin, M. D., and Brasitus, T. A. (1990) 1,25(OH)2 vitamin D3 stimulates membrane phosphoinositide turnover, activates protein kinase C, and increases cytosolic calcium in rat colonic epithelium. J. Clin. Invest. 85 , 1296-1303.

Wang, Q. M., Jones, J. B., and Studzinski, G. P. (1996). Cyclin-dependent kinase inhibitor p27 as a mediator of the G1-S phase block induced by 1,25-dihydroxyvitamin D3 in HL60 cells. Cancer Res. 56, 264-267.

Woo, T. C. S., Choo, R., Jamieson, J. Chander, S., and Vieth, R. (2005). Pilot study: potential role of vitamin $\mathrm{D}$ (cholecalciferol) in patients with PSA replapse after definitive therapy. Nutr. Cancer 51, 32-36.

Yin, L., Grandi, N., Raum, E., Haug, U., Arndt, V., and Brenner, H. (2009). Meta-analysis: longitudinal studies of serum vitamin D and colorectal cancer risk. Aliment. Pharmacol. Ther. 30, 113-125.

Zabel, M., Flig, K., Gebarowska, E., and Surdyk-Zasada, J. (2003). The effect of calcitriol and its analogues on proliferation and hormone expression in cultured cells of thyroid medullary carcinomas. Folia Morphol. (Warsz.) 62, 463-465.
Zhou, J. Y., Norman, A. W., and Chen, D. L. (1990). 1,25-Dihydroxy-16ene- 23-yne-vitamin D3 prolongs survival time of leukemic mice. Proc. Natl. Acad. Sci. U.S.A. 87, 3929-3932.

Zinser, G. M., and Welsh, J. (2004). Effect of Vitamin D3 receptor ablation on murine mammary gland development and tumorigenesis. $J$. Steroid Biochem. Mol. Biol. 89-90, 433-436.

Conflict of Interest Statement: The authors declare that the research was conducted in the absence of any commercial or financial relationships that could be construed as a potential conflict of interest.

Received: 06 February 2012; paper pending published: 20 February 2012; accepted: 04 April 2012; published online: 23 April 2012.

Citation: Vuolo L, Di Somma C, Faggiano A and Colao A (2012) Vitamin D and cancer. Front. Endocrin. 3:58. doi: 10.3389/fendo.2012.00058

This article was submitted to Frontiers in Cancer Endocrinology, a specialty of Frontiers in Endocrinology.

Copyright (c) 2012 Vuolo, Di Somma, Faggiano and Colao. This is an open-access article distributed under the terms of the Creative Commons Attribution Non Commercial License, which permits noncommercial use, distribution, and reproduction in other forums, provided the original authors and source are credited. 